\title{
Journey through the Defences of the Festung Saint-Malo (FR)-2
}

\author{
Giancarlo T. Tomezzoli, Louis L. Pottier* \\ Etno-Archaeological Observatory, Munich, Germany \\ Email: *gt21949@gmx.de
}

How to cite this paper: Tomezzoli, G. T., \& Pottier, L. L. (2016). Journey through the Defences of the Festung Saint-Malo (FR)-2. Archaeological Discovery, 4, 143-169. http://dx.doi.org/10.4236/ad.2016.44011

Received: August 10, 2016

Accepted: October 17, 2016

Published: October 20, 2016

Copyright $\odot 2016$ by authors and Scientific Research Publishing Inc. This work is licensed under the Creative Commons Attribution International License (CC BY 4.0).

http://creativecommons.org/licenses/by/4.0/

\begin{abstract}
During the WWII the Organisation Todt constructed in behalf of the Wehrmacht (German Army), Luftwaffe (German Air Force) and Kriegsmarine (German War Fleet) many military structures for the defence of the Festung (Fortress) Saint-Malo (Brittany, France). A previous article (Tomezzoli \& Pottier, 2016) presented military structures for the east side defence of the Festung and their preservation state. This article presents other military structures, in some case completely disappeared, for the defence of the city port and the south-west side of the Festung. Their historical, military interest and their actual preservation state are analysed.
\end{abstract}

\section{Keywords}

Saint-Malo, Festung, France, Atlantic Wall, World War II, Military, German

\section{Introduction}

During the WWII the Organisation Todt constructed in behalf of the Wehrmacht (German Army), Luftwaffe (German Air Force) and Kriegsmarine (German War Fleet) many military structures for the defence of the Festung (Fortress) Saint-Malo (Brittany, France). A previous article (Tomezzoli \& Pottier, 2016) presented military structures for the east side defence of the Festung and their preservation state. This article describes some other structures, in some case completely disappeared, located in the city port and along the Frémur river for the defence of the south-west side of the Festung (Figure 1).

\section{Defence of the City Port}

The Hafens Verteidigungs Plan (port defence plan) (Pottier, 2014a) (Figure 2(a) and Figure 2(b)) dated April 1944 of the German Headquarter of the Festung Saint-Malo shows that the German defences of the Hafen (port) were constituted by the following 
Stutzpunkte (support points): St.P. 276, St.P. 235 positioned on the West of the city (Intra Muros); St.P. 272 on the surface of the pier (Molenfussgang) in front of the main entrance to the city; St.P. 274, St.P. 226 in the area of the sluices (Schleusenverteidigung); St.P. 273 at the advanced head of the piers (Molenkopfen); St.P. 230 at the entrance to the port; St.P. 238 inside the internal basin (Bassin Interieur) and St.P. 275 near the Bouvet basin (Bassin Bouvet). The St.P. 226, St.P. 235 and St.P. 238 were serviced respectively by the Luftwaffe companies IV./4.912, III./1.912, V./4.912. The St.P. 230, St.P. 272, St.P. 273, St.P. 274, St.P 275 and St.P. 276 were serviced respectively by the Kriegsmarine uInf.Fest.St.Komp 1.LXXIV Stamm (Marine Infantery Fortress Static under Company 1./LXXIV), HaKo WachKomp (Hafen Kommando Wach Kompanie-Port Commandment Guard Company), Ausrustung (Armament) and the II.Batt. M.A.A. 608 (II. Batailion Marine Artillerie Abteilung 608-II. Battalion Marine Artillery Group 608). The map also provides information about the specific armament of each support point. It is therefore possible to see that with the exception of St.P. 276 which comprised $4 \times 10.5 \mathrm{~cm}$ guns (Haubhitze - howitzer), all the other St.Ps. comprised close defence small calibre guns: $2.0 \mathrm{~cm}$ Flak guns, $2.5 P a K$ guns, $5 \mathrm{~cm} \mathrm{KWK}$ guns. The armament was completed by armoured dome bunkers (Panzerkuppel),

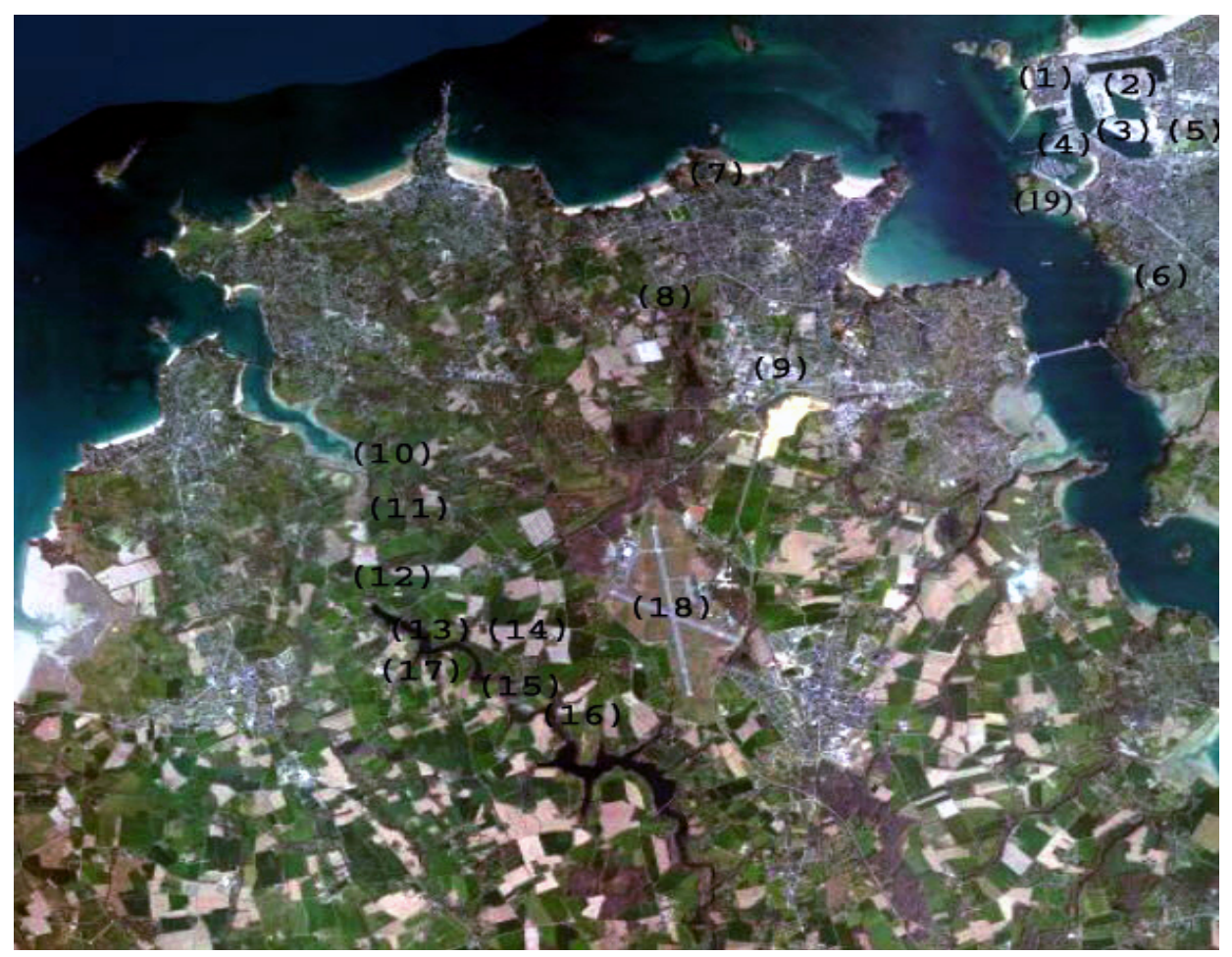

Figure 1. Festung Saint-Malo-German military structures in the port and on the south-west part of the Festung. (1). Saint-Malo city-Intra-Muros, (2). port, (3). degaussing station, (4). inflating hangar for "sausages", (5). Moka's Kriegsmarine first aid bunker, (6). La Briantais St.Pentrenched camp, (7). La Roche Pelée St.P. Ra 136-artillery battery, (8). La Brousette St.P. Ra 157-artillery battery, (9). La Ville es Meniers St.P.—artillery battery, (10). W. 685, (11). W. 682, (12). S. 680, (13). W. 675, (14). S. 236, (15). W. 672, (16). S. 670, (17). German railway bridge (18). Airfield of Dinard-Pleurtuit, (19). Cité d'Aleth [Flash Earth]. 


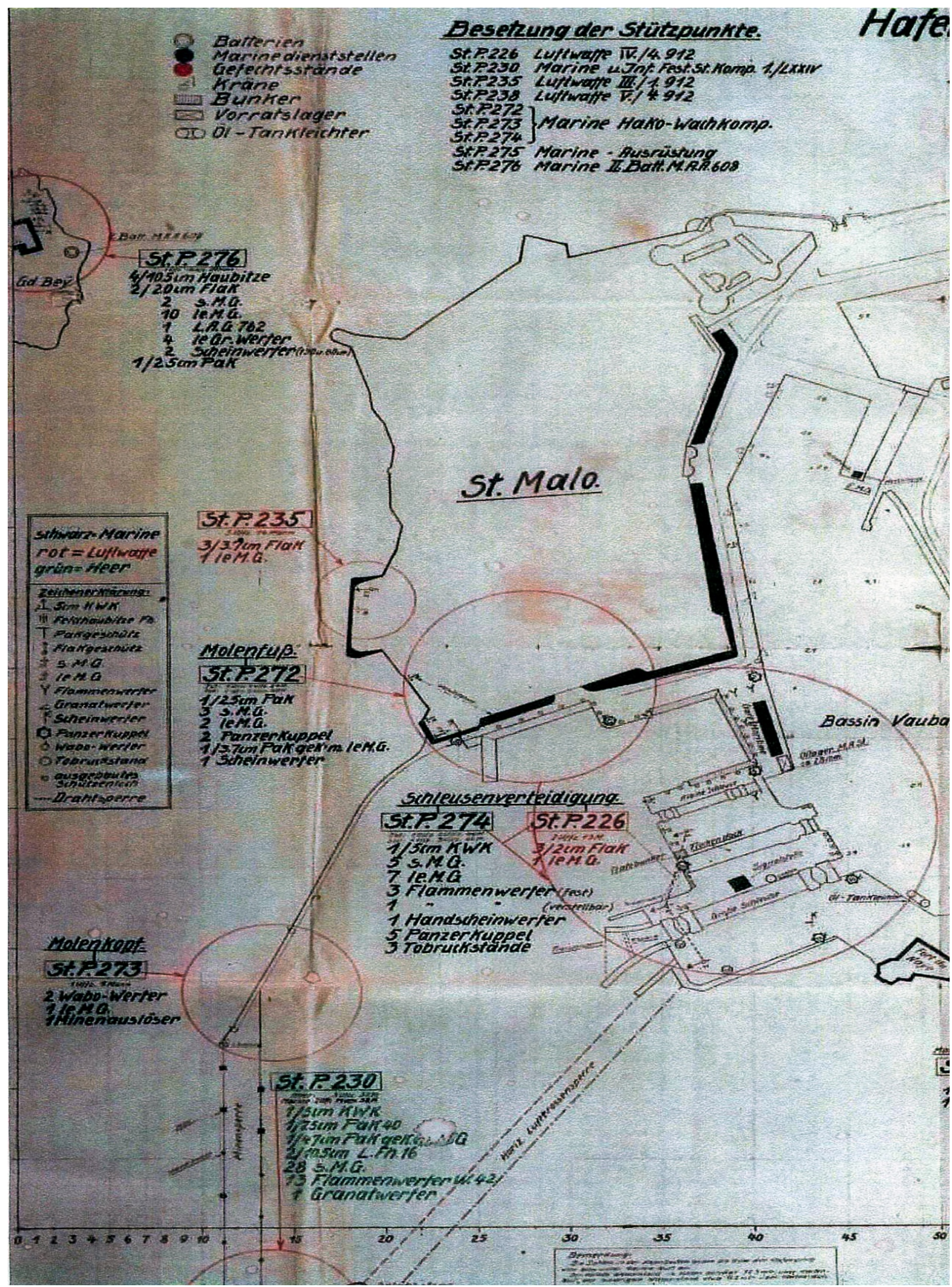

(a) 


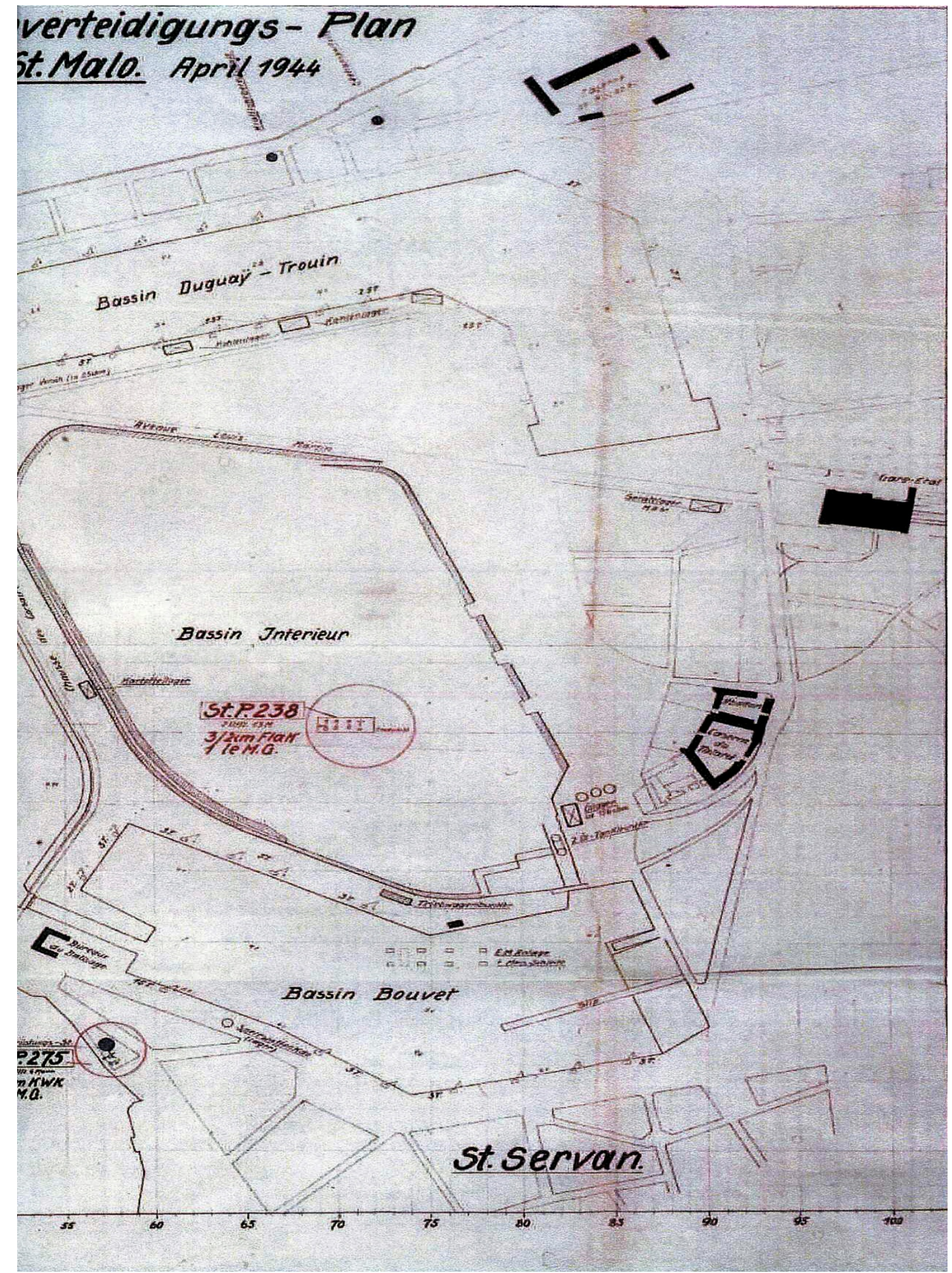

(b)

Figure 2. (a) Festung Saint-Malo: defences of the port-on the upper side Saint-Malo (Intra-Muros), on the lower side the sluices of the port (Pottier, 2014a); (b) Festung Saint-Malo: defences of the port-in the upper side of the Bouvet basin the black rectangle marking the degaussing station bunker (Pottier, 2014a). 
flamethrower bunkers (Flammenwerfer), Tobruck stands (Tobruckstände), mortar stands (Granatwerfer), projectors stands (Scheinwerfer) and the light personal armament of the personnel.

The German Headquarter map appears to be the official list of the St.P.s, although in another publication (Sakkers, 2001) they are listed as S. (St.P.) and W. (Widerstandsnesteresistance nests) as follows: S. 226 (Flak-Stellung_antiaircraft stand); S. 230 (Festung-fortress); S. 235 (Flak-antiaircraft); S. 238 (Flak-Stellung—antiaircraft stand); W. 272, W. 273 (Mole - Marine Anlage--pier - Marine plants), W. 274 (Schleuse - Marine Anlage-sluice - Marine plant); W. 275 (Marine. Anlage-Marine plant); S. 276 (Grand Bey Marine Anlage - M.K.B-Grand Bey Marine plant-Marine coast battery). The fire of the St.P.s and/or W.s of the port was supported by far defence artillery batteries positioned around the city at Saint Coulomb (Ra 110) (Tomezzoli, 2016), La Brousette (Ra 157), La Ville es Meniers and at the Île de Cezambre (Ra 277).

It is observed that, after the conclusion of the operation Seelowe (Sea Lion) and the Battle of Britain in November 1941, the nearby airfield of Dinard-Pleurtuit (Figure 1) (Dahiot et al., 2009) (Tomezzoli et al., 2013) (Tomezzoli, 2014) hosted no important Luftwaffe air units, therefore practically no relevant contribution for the defence of the Festung arrived from it.

After the war, during the reconstruction of Saint-Malo, all the St.Ps in the port were demolished. Nowadays, only here and there some component of them remains visible and accessible. This is the case of a Panzerstellung Bauform 67 (armoured stand construction type 67) (Figure 3 and Figure 4) for an armoured, fully rotatable APX-R turret of a captured French WWI Renault FT light tank, equipped with a $8 \mathrm{~mm}$ machine gun or a $37 \mathrm{~mm}$ gun. It is located on the pier surface near the main entrance to the Intra-Muros $\left(48^{\circ} 38^{\prime} 44.5^{\prime \prime} \mathrm{N}, 02^{\circ} 01^{\prime} 32.1^{\prime \prime} \mathrm{W}\right.$ ) and belonged to the Molenfu St.P. 272 (Figure $2(\mathrm{a})$ ). The concrete structure, filled with gravel, appeared, at the moment of the visit on 2010, well preserved with only superficial damages apparently not due to combats (Figure 3, Figure 4(a)). The APX-R turret disappeared and only its mounting plate with the rotation rack remained visible on the concrete structure (Figure 4(b)). An entrance in the concrete structure, if any, has not been identified, therefore, it is also possible that the bunker was only accessible through the turret.

\section{Degaussing Station}

The activities of the Kriegsmarine in Saint-Malo during the WWII are well documented (Brichet, 2005). The presence of a degaussing station in the port is known (Brichet, 2005), although its structure and operation are much less known. But, fortunately, precise information about it, we received through secret and confidential reports by persons that inspected it just at the end of the WWII.

In a note dated 23 April 1945, the Capitaine de Corvette (lieutenant commander) G. De La Bretesche wrote that the degaussing station comprised a control post in Saint-Malo and a degaussing post with local control post on the dock of the Saint-Servan basin (ed.: or Bouvet basin) (Figure 1, Figure 2(b)). The control posts 


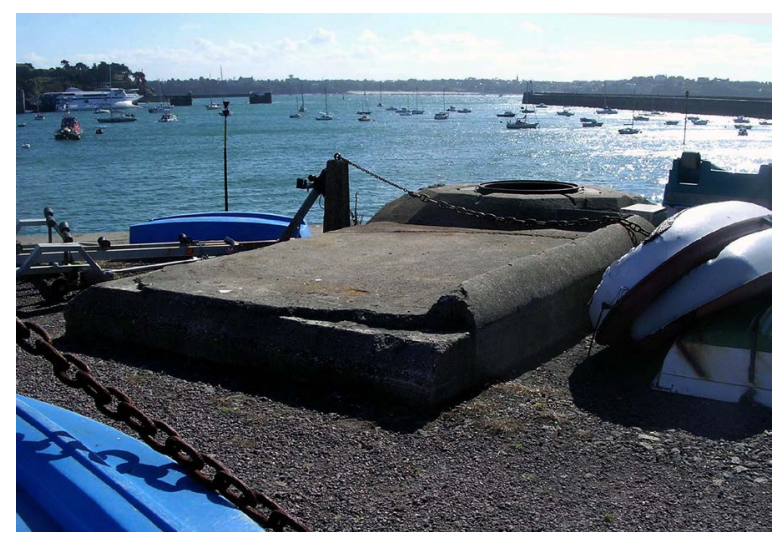

Figure 3. Panzerstellung Bauform 67-concrete structure, on the left superficial damages, on the right mounting plate for APX-R turret of a captured French WWI Renault FT tank.

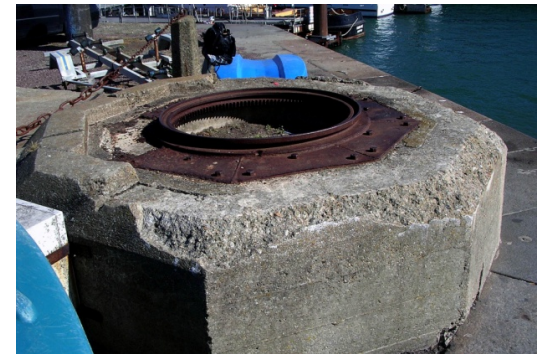

(a)

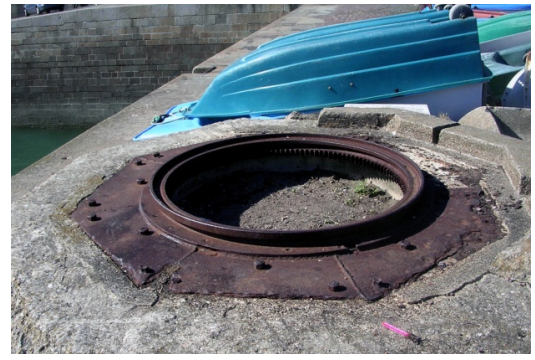

(b)

Figure 4. Panzerstellung Bauform 67-(a) minor damages to the concrete structure, (b) APX-R turret mounting plate with rotation rack.

were completely destroyed (ed.: during the Saint-Malo battle in August 1944). The degaussing station, burned by the Germans, was mounted on (ed.: a railway) automotive enclosed in a concrete bunker. The automotive itself (chassis) had not too much suffered for the fire, the traction group (diesel, dynamo) could still be repaired. The generator for degaussing had suffered more, but it appeared for the most part recoverable. The loop cables for the degaussing of the ships were buried in the mud of the SaintServan basin, but they could be recovered (Pottier, 2014b).

In a non-dated letter Mr. Marcel Halna author of the drawing of Figure 5, wrote that the station was used more for the degaussing of French trawlers armed by the Germans than for the true minesweepers, because these last, being of military origin, had already their own anti-magnetic belt. Sheltered in the bunker, there was an automotive, but more precisely it was a big wagon, equipped by one or two powerful generators for feeding electric cables loops at the bottom of the basin, under the water, in front of the bunker with an electrical current of very high voltage and amperage. For degaussing their metal shells, the trawlers should necessarily pass on the cable loops three or four times. The orders for the degaussing were given to the ships by means of a loud speaker. The portion A-B of the railway (ed.: Figure 5, connecting the bunker to the French railway network) was for a certain period covered with terrain in order to not be spotted by the allied (ed.: aircrafts) (Pottier, 2014c). 


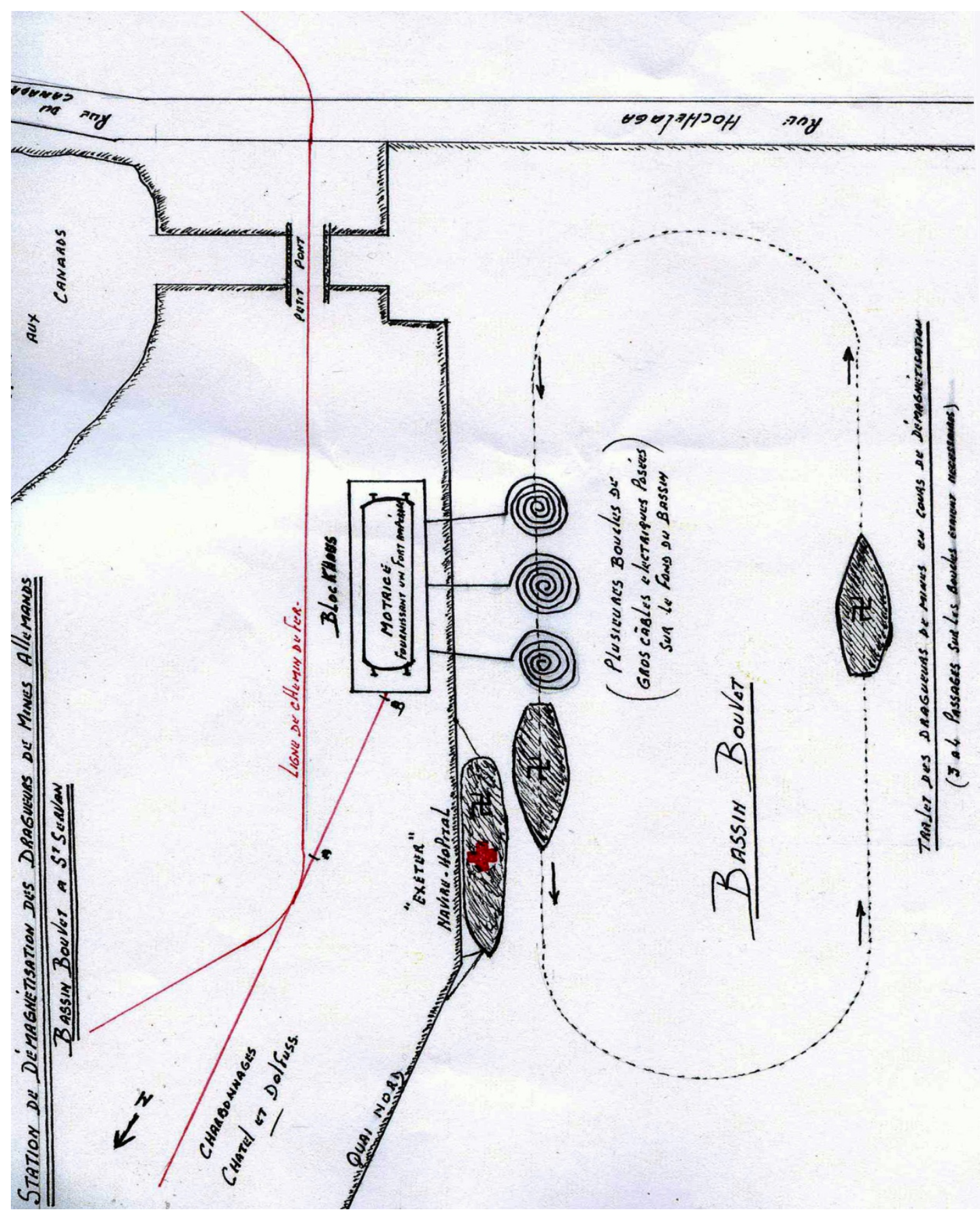

Figure 5. Saint-Malo port-Halna's drawing of the degaussing station: Blockhaus or bunker position $\left(48^{\circ} 38^{\prime} 31.7^{\prime \prime} \mathrm{N}, 02^{\circ} 00^{\prime} 47.7^{\prime \prime} \mathrm{W}\right)$, electric loop cables in the Bouvet basin and the portion A-B of the railway connecting the bunker to the French railway network covered with terrain.

The bunker (Figure 6), probably a Sonderkonstruktion (special construction), was about $35 \mathrm{~m}$ long, $15 \mathrm{~m}$ wide and $5 \mathrm{~m}$ high. Because of its considerable dimensions, probably, it sheltered not only the railway automotive but also materials and equipment of the station. It was demolished in the years 1974-75. The automotive or big wagon was certainly a German diesel-electric locomotive or a French one model 262 AD1 or 
262 BD1 (Figure 7) as that in use at the German submarine base of La Pallice. The eight rectangles in the Bouvet basin (Figure 2(b)) in front of the bunker indicate the tags delimiting the path that a trawler ships should navigate for passing on the loop cables. The German hospital ship Exeter was docked near the bunker so as to forbid the bombing of the place and in this way to protect the bunker and the loop cables. It was bought by the German ship-owner H. M. Gehrkens of Hamburg on 1924. Requisitioned on 1940 by the Kriegsmarine and transformed in hospital ship, which ensured her safe navigations, she transported concrete, ammunitions and materials necessary for the defence to the Channel Islands under German Occupation. She was sunk near the Porte de Dinan on 7 June 1944 for blocking to the Allied the access to the port and refloated after the war.

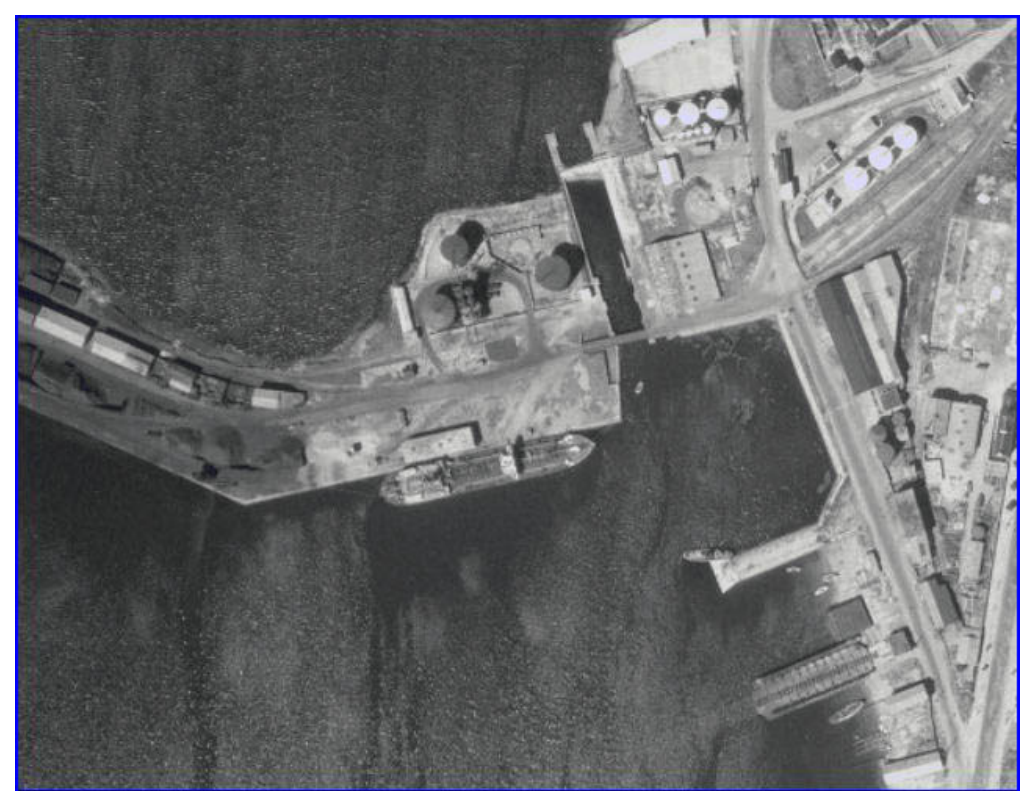

Figure 6. Saint-Malo port-in the middle the degaussing station bunker, image of 26/07/1952, close to the bunker a tanker ship and on the upper right side the rebuilt tanks of the oil terminal du Thalard IGNF_PVA_1-0_1952-07-26_C1115-0101_1952_CDP3680_0227.

$262 A D .1$

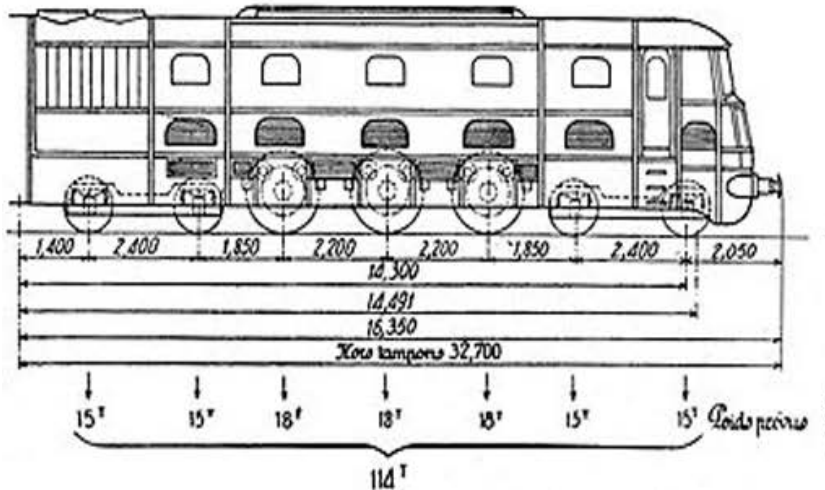

262. 80.1

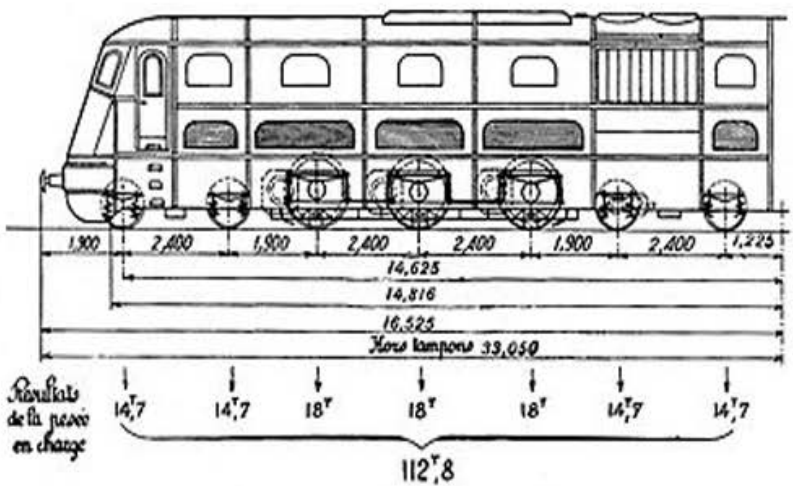

Figure 7. French diesel-electric locomotive 262 AD.1, 262 BD.1 (Wikipedia, 2015). 


\section{Inflating Hangar for "Sausage"}

Mr. Alna in said non-dated letter (Pottier, 2014b) reported that on the Esplanade Saint-Vincent, near Intra-Muros, on the North of the port sluice was a big, metallic hangar (Figure 8), in which the personnel of the Kriegsmarine stored and inflated "sausages" balloons. The ships that gone in convoy to the occupied Channel Islands, towed at several hundred meters above them these balloons, so as to prevent allied aircraft to strafe by swooping on them vertically. On the allied side existed the same tactics. One day, one of said balloon was hit by the lightening and exploded in a fireball in the sky (Pottier, 2014b). The hangar (Beroul, 1982) was demolished shortly after the WWII.

Figure 8 shows on the right the ferry La France, $58 \mathrm{~m}$ long, built in England on 1915. Purchased by the Compagnie Franco-Hollando-Américaine, she was based at Boulogne sur Mer. At the outbreak of the WWII she was requisitioned by the French Navy as the minelayer X 31. She was in St Malo in June 1940 upon the arrival of the Germans troops. Requisitioned by the Kriegsmarine, from the summer 1942 she was used as transport ship for supplying the Channel Islands with troops and materials. On 18 June 1944, arriving in St Malo from Jersey, she was sunk during an allied air attack. Refloated after the war, she resumed service at Cherbourg for the Société Cherbourgeoise de Remorquage et de Sauvetage (Feige, 2011) (Brouard et al., 2009).

\section{The Moka’s Kriegsmarine First Aid Bunker}

A large, square shaped, Kriegsmarine first aid bunker R661 (Unterstand für Verwundetensammelstelle-shelter for wounded collection) (Figure 9 and Figure 10) was built on 1942 on the College Moka-Sainte Famille estate, facing the lines of the old SaintMalo railway station. It was built by the Organisation Todt in less than two months, by reinforced concrete consolidated by flint stones of Normandy and Loire river. It comprised two big rooms: a surgical room, provided with white tiles up to the half of its

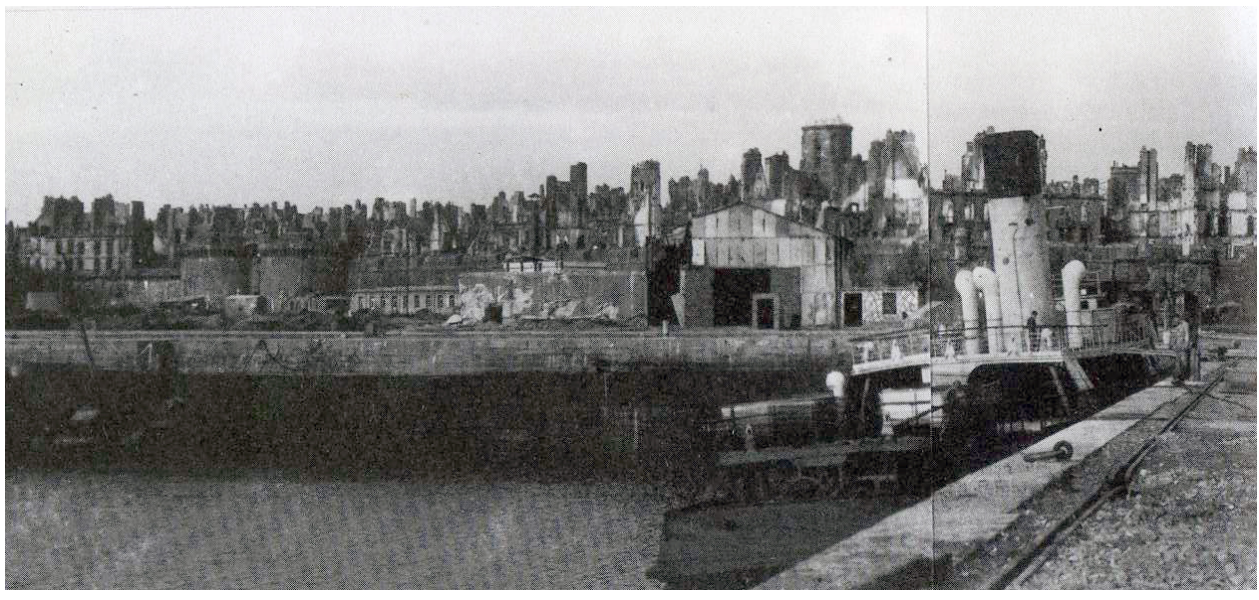

Figure 8. Saint-Malo port-in the middle-right the metallic inflating hangar with the doors opened $\left(48^{\circ} 39^{\prime} 1.8^{\prime \prime} \mathrm{N}, 02^{\circ} 01^{\prime} 22.7^{\prime \prime} \mathrm{W}\right)$, on the right the ferry La France and in the background the ruins of Saint-Malo after the battle (Beroul, 1982: p. 108). 


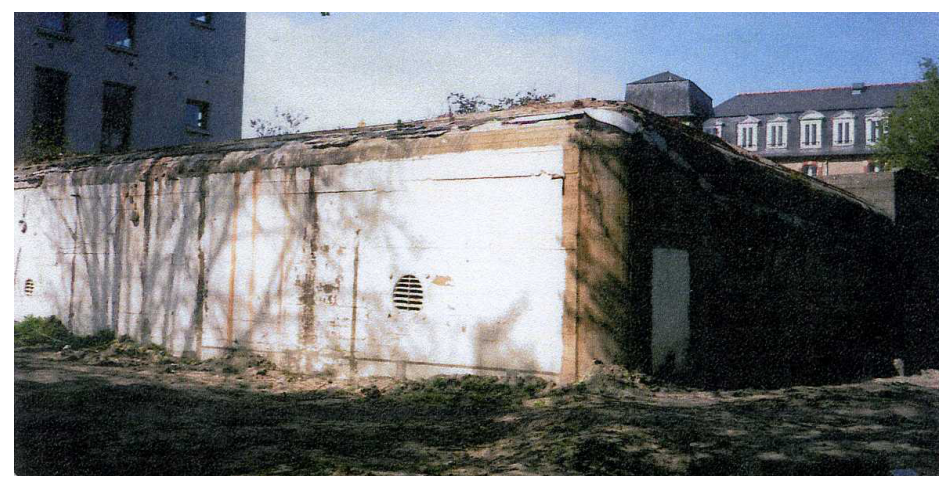

Figure 9. Moka's Kriegsmarine first aid bunker R661 (48 $\left.38^{\prime} 51.0^{\prime \prime} \mathrm{N}, 2^{\circ} 0^{\prime} 13.2^{\prime \prime} \mathrm{W}\right)$, external details with the armored air intakes of the ventilation system.

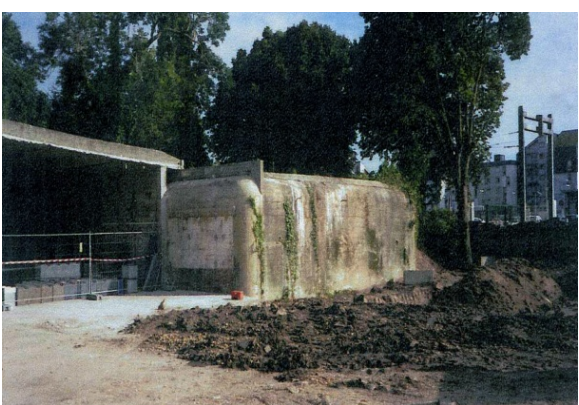

(a)

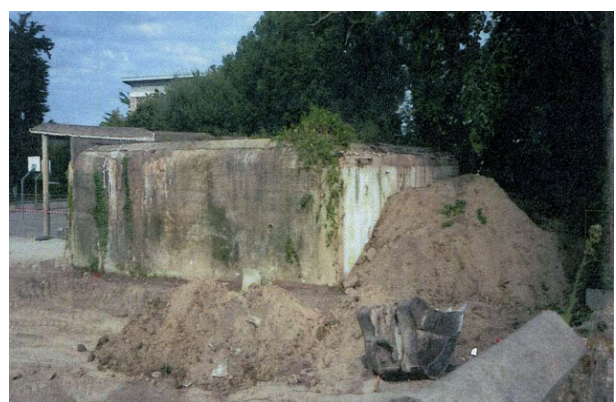

(b)

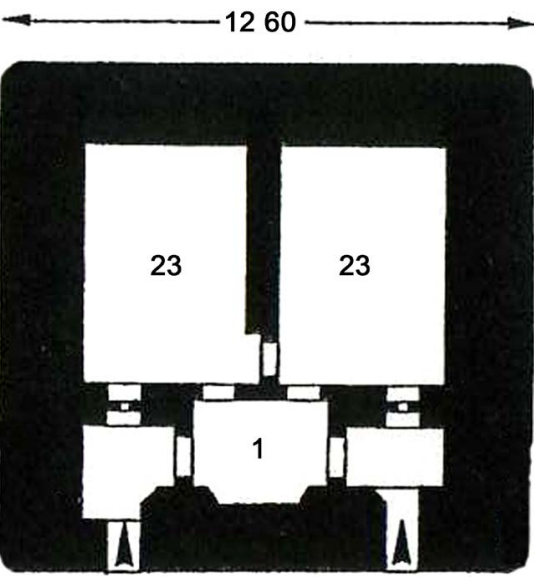

(d)

Figure 10. Moka's Kriegsmarine first aid bunker R661-(a), (b) external details of the concrete structure, (c) red cross on an external bunker wall; (d) R661 bunker plan: 1. gas lock, 23. surgical unit and wounded rest room (Rudi, 1988).

height, and a rest room for the wounded. The bunker had $2 \mathrm{~m}$ thick walls; hard to pierce, that allowed the military surgeons to operate safely during the Saint-Malo battle. The nuns of the Mokás Collège's Chapel mentioned the bunker in a now unobtainable booklet, in which they told to have discovered bodies of soldiers and ammunitions abandoned around it at the moment of the Liberation of Saint-Malo. After the WWII the bunker rooms were used for carpentry courses before to be converted in store 
rooms.

The visit took place on 2010 and permitted to verify that the concrete structure of the bunker was well preserved without damages due to combats. On one face, although practically erased, a big red cross was still visible. At the interior the operating room and the rest room were devoid of all the original furniture.

On 2011 the bunker was demolished for providing space for a real estate project of about hundred lodgings. The demolition was not easy and required the development of special techniques. Because of the bunker size and its position in the city (Figure 9), the use of sticks of dynamite was inconceivable. Therefore, the firm Karavis from Rennes drilled in the concrete 650 holes of different depth in which expansive gas cartridges were slipped. Then, the bunker was enveloped with hay bales covered by plastic sheeting, a new way for limiting the dispersion of concrete debris and mitigate noise and vibrations in the ground. The cartridges explosion weakened the bunker walls opening cracking everywhere. The debris was evacuated by the city public services.

\section{La Briantais St.P.—Entrenched Camp}

The castle of La Briantais (Figure 11), was built on in 1864 by Eugene Sully-Brunet and extended on 1900 with two side wings by Charles La Chambre. It was requisitioned on 1940 after the Occupation for accommodating the staff of the Oberbauleitung (upper construction direction) Saint-Malo of the Organisation Todt). A bunker was built in the park, near the castle for protecting the staff in case of attacks. Shortly before the outbreak of the Saint-Malo battle, the park was rapidly transformed into an entrenched camp. On 9th August 1944 surrounded by US troops and at the moment to undergo the final assault, the defenders got a ceasefire. During it, they contacted by phone the Festung Headquarter, which activated a barrage fire by the Cezambre Island guns. The Americans retreated but cut the telephone lines isolating the defenders, which soon after surrendered (Dupont, 1994).

The visit park took place on 19th August 2011 and permitted to ascertain that all the structures of the entrenched camp disappeared, either demolished or covered by terrain, instead, the bunker for protection the personnel (Figures 12-16) was easily identified. It was completely covered by terrain except for the concrete portions of the entrances, which were in a good preservation state, without damages due to combats. The bunker preserved the original armored, metallic doors. The interior of the bunker was not accessible; therefore the disposition of the rooms and their preservation state was not assessed. The terrain coverage and the inaccessibility of the interior did not permit to determine the bunker type.

\section{Pointe de la Roche Pelée St.P. Ra 136-Artillery Battery}

The Pointe de la Roche Pelée St.P. artillery battery AOK 7, KVA A1, KvGr Rance, Festung Saint-Malo, Ra 136 is located near the nowadays Hôtel Novotel Thalassa. It comprised a Vf observation bunker, a tobruck stand 58c and a bunker R667 integrated in the cliff, without annexed rooms but provided with a protection wall for the fire 


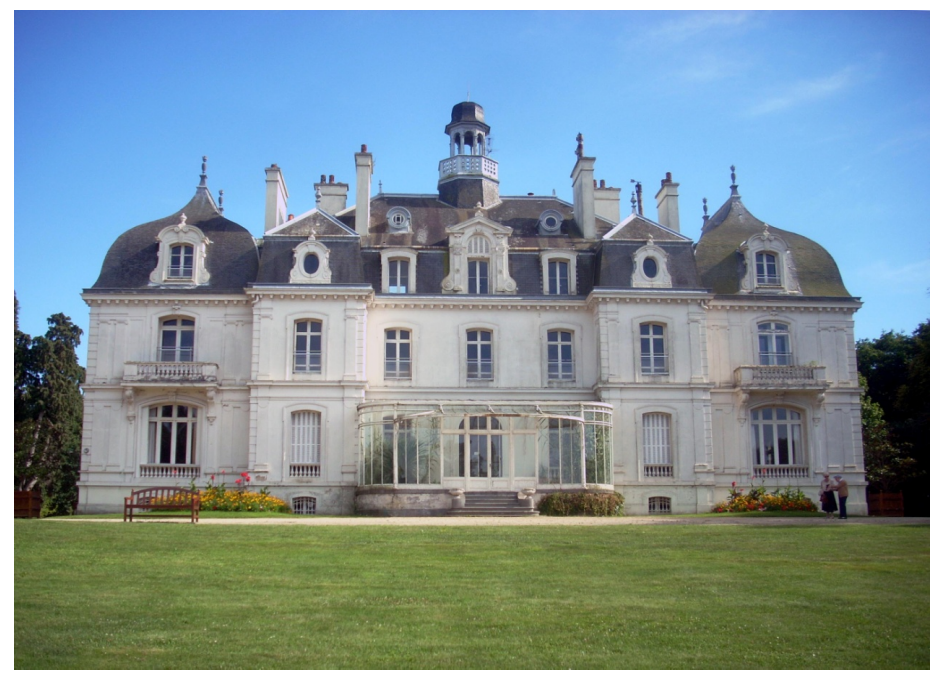

Figure 11. La Briantais castle-the bunker for protection of the personnel $\left(48^{\circ} 37^{\prime} 04.2^{\prime \prime} \mathrm{N}\right.$, $02^{\circ} 01^{\prime} 48.5^{\prime \prime} \mathrm{W}$ ) is about $50 \mathrm{~m}$ on the left.

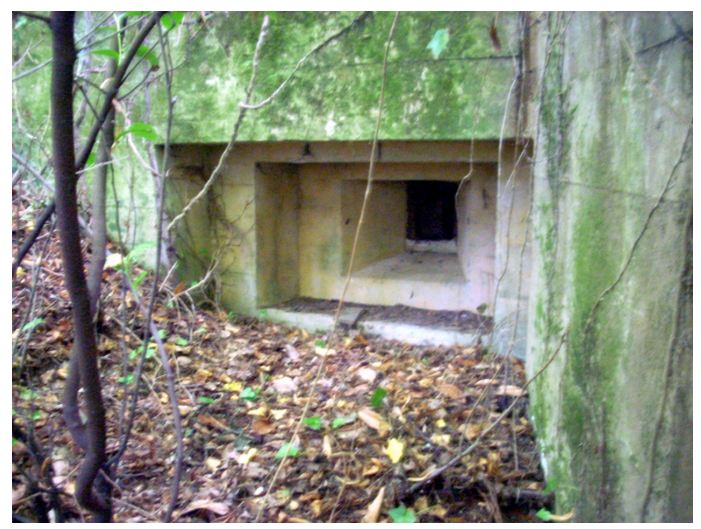

Figure 12. La Briantais St.P—entrenched camp—-protecting staff bunker, external embrasure of a close combat room.

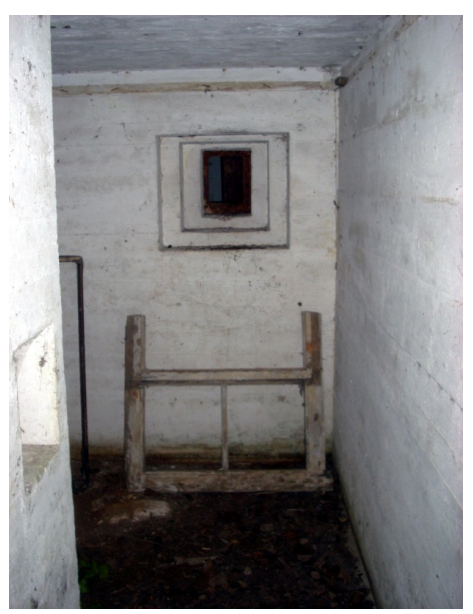

(a)

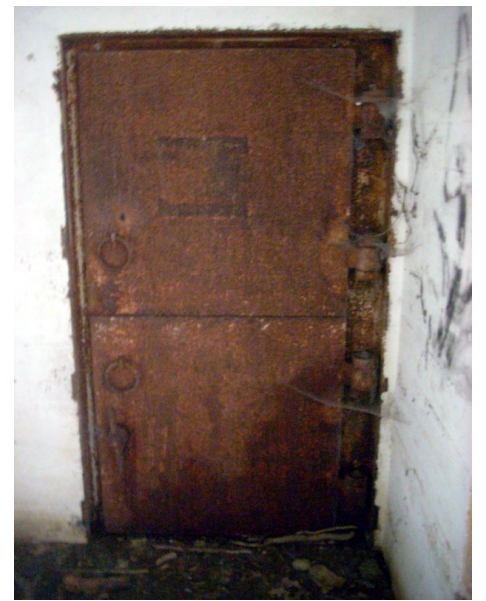

(b)

Figure 13. La Briantais St.P.-entrenched camp-(a) bunker entrance corridor with internal embrasure of a close combat room, (b) bunker original entrance armored door. 


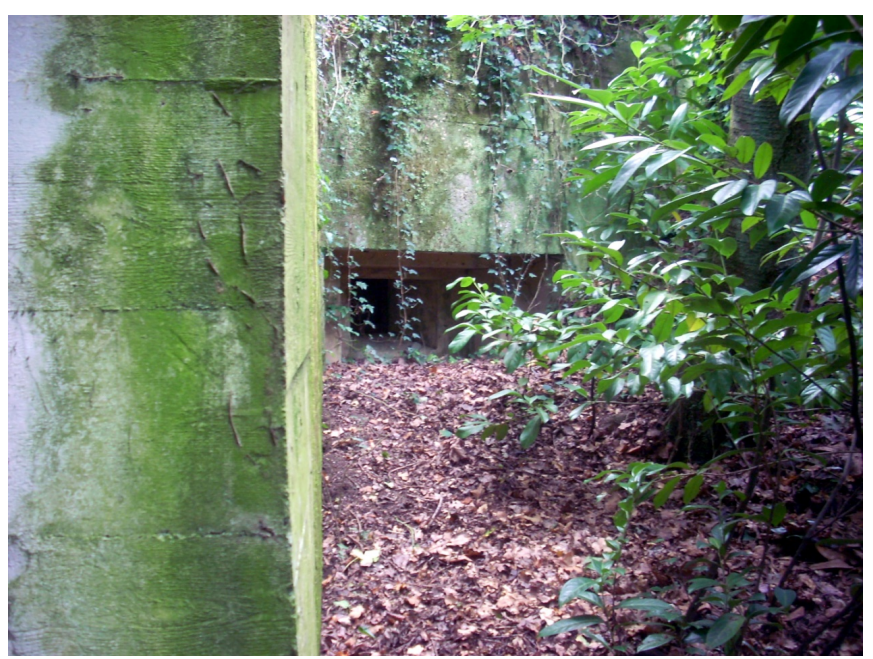

Figure 14. La Briantais St.P.—entrenched camp—protecting staff bunker, external embrasure of a close combat room.

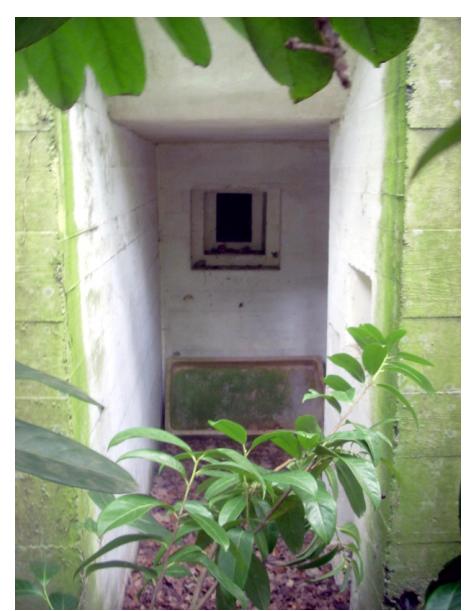

(a)

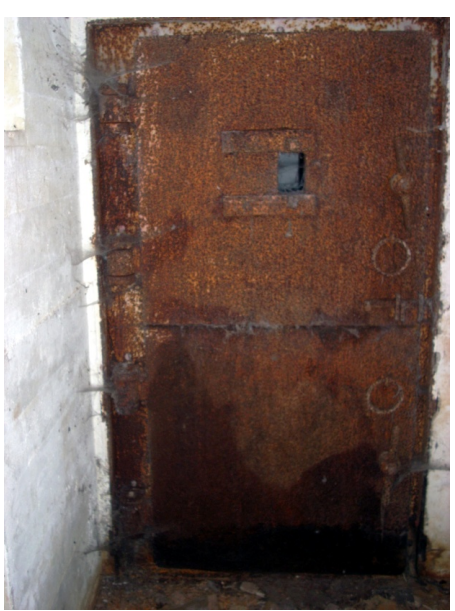

(b)

Figure 15. La Briantais St.P.-entrenched camp-(a) bunker entrance corridor with internal embrasure of a close combat room, (b) bunker original entrance armored door.

room aperture and a side protective wing (Figure 17 and Figure 18).

Our visit took place on 2nd August 2012 and permitted only to identify and visit the bunker R667. The preservation of its concrete structure is good without damages due to the combats (Figure 18). The fire room for an $88 \mathrm{~mm} \mathrm{Pak} \mathrm{43/41} \mathrm{was} \mathrm{degraded} \mathrm{by} \mathrm{ter-}$ rain and water on the floor. The original internal furniture disappeared and the thermal insulation material on the walls of the fire rooms were either never installed or disappeared. The gates of the combat gas extraction system disappeared, letting visible the interior of the air intakes of the system (Tomezzoli \& Pottier, 2016). The Vf observation bunker and the tobruck stand $58 \mathrm{c}$ were not localised.

\section{La Brousette St.P. Ra 157-Artillery Battery}

La Brousette St.P. artillery battery AOK 7, KVA A1, KvUGR, Festung Saint-Malo, Batt. 
6/A.R. 177, Ra 157 was composed by four bunkers R669 without annexed rooms. The absence of a fire direction bunker near the bunkers R669, as in the case of the Kullak battery (Tomezzoli, 2016), let to think that the battery fire was directed by an observatory bunker located somewhere else.

Our visit took place on August 2003 and permitted to ascertain that the bunkers, although covered by the vegetation, have their concrete structures in a good preservation state without damages due to the combats. They were deprived of the original internal furniture and reused as store for agricultural devices (Figure 19 and Figure 20).

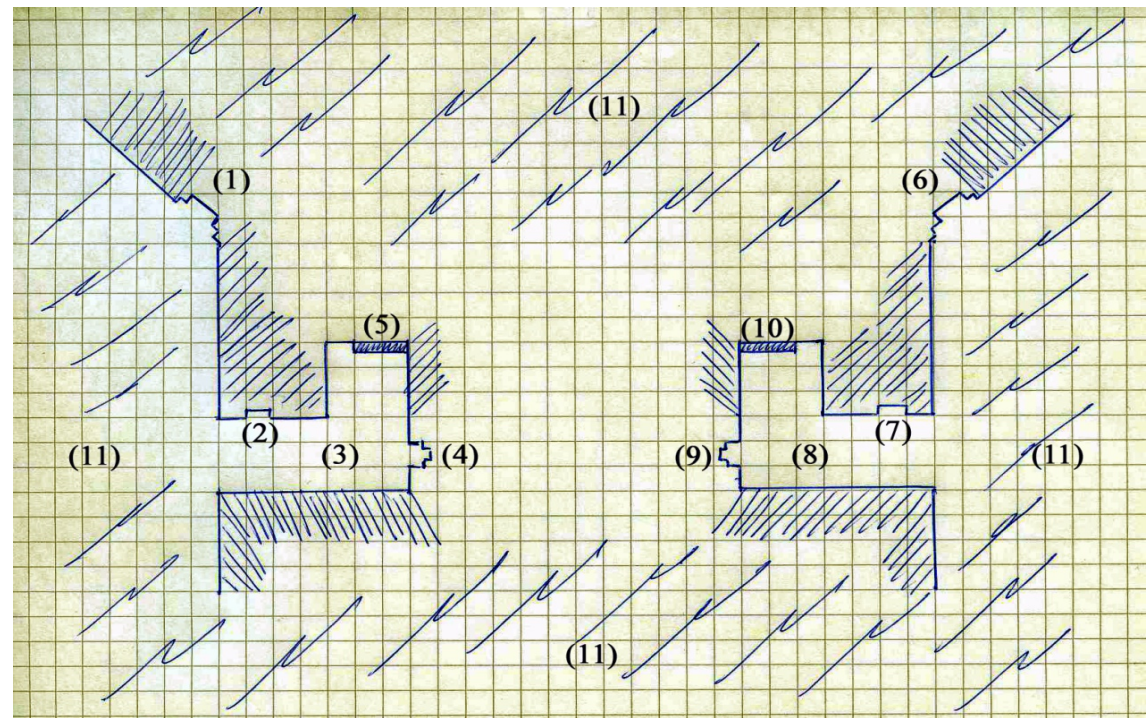

Figure 16. La Briantais St.P.—entrenched camp-plan of the accessible parts of the protecting staff bunker: (1). external embrasure of a close combat room, (2). niche, (3). entrance corridor, (4). internal embrasure of a close combat room, (5). original armoured entrance door, (6). external embrasure of a close combat room, (7). niche, (8). entrance corridor, (9). internal embrasure of a close combat room, (10). original armoured entrance door, (11). ground terrain.

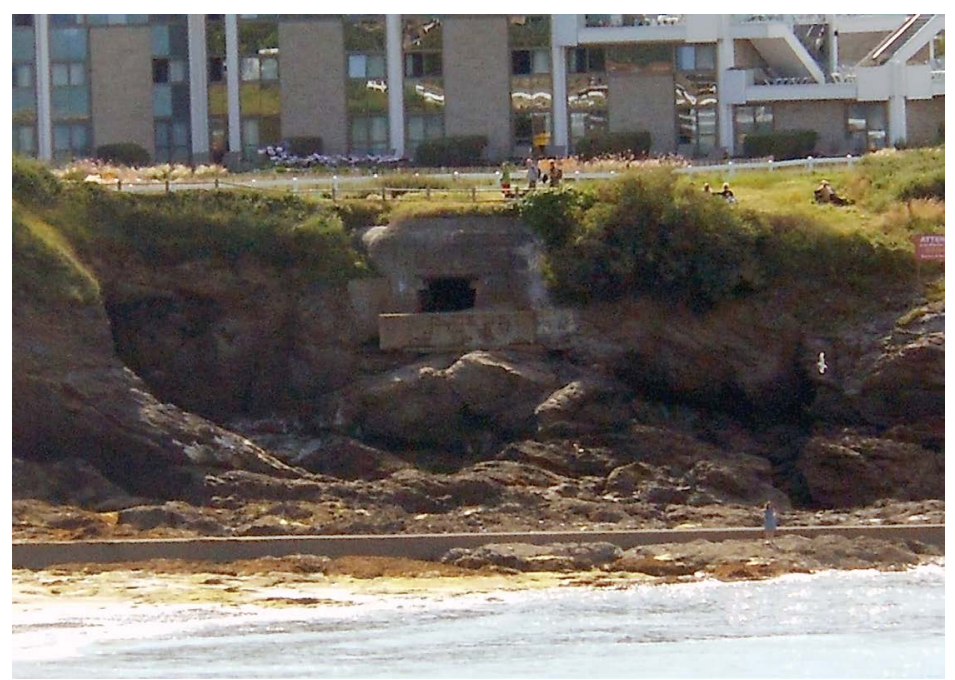

Figure 17. Pointe de la Roche Pelée St.P.—artillery battery-R677 bunker $\left(48^{\circ} 38^{\prime} 22.1^{\prime \prime} \mathrm{N}, 2^{\circ} 38^{\prime}\right.$ 23.2"W) integrated in the cliff, in the foreground the Hôtel Novotel Thalassa. 


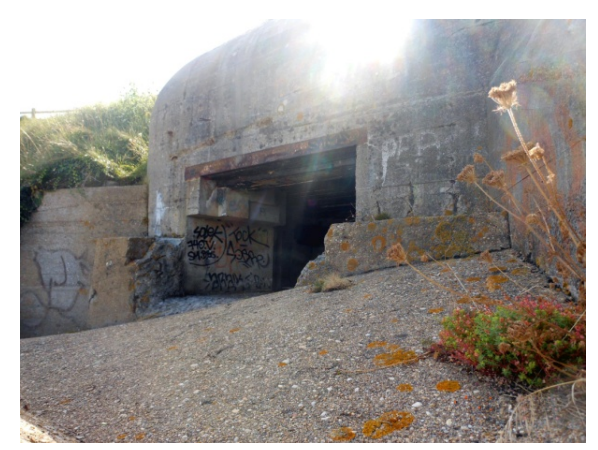

(a)

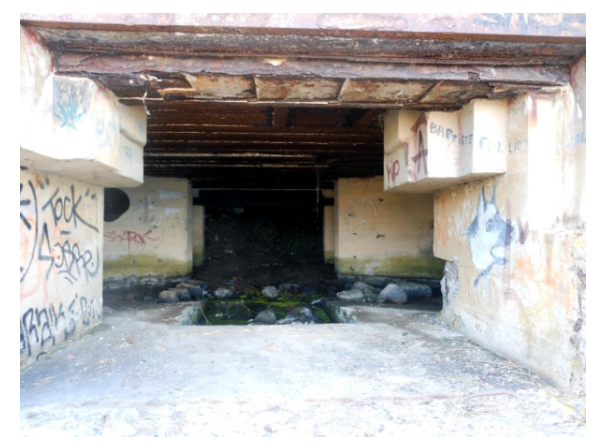

(c)

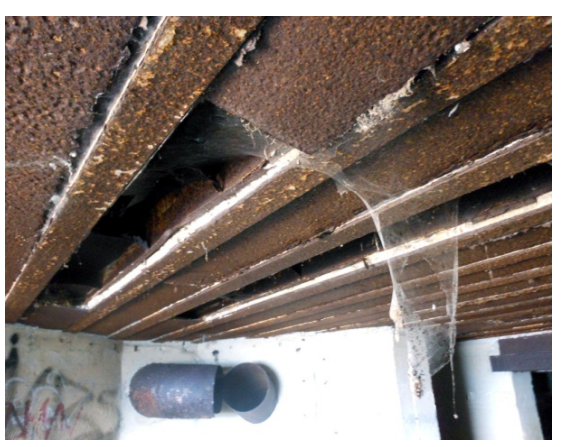

(e)

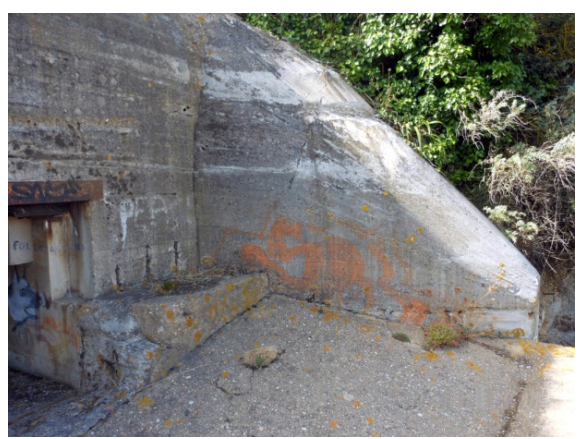

(b)

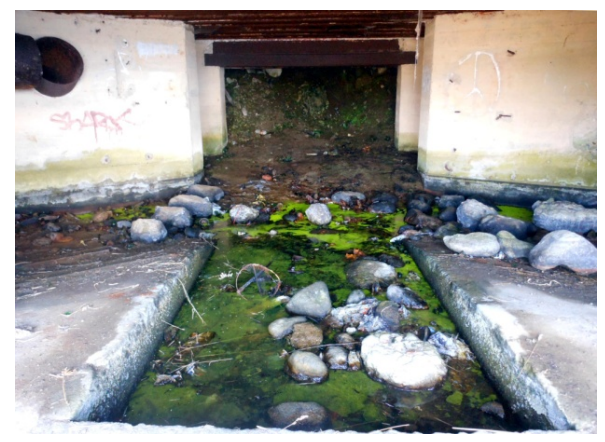

(d)

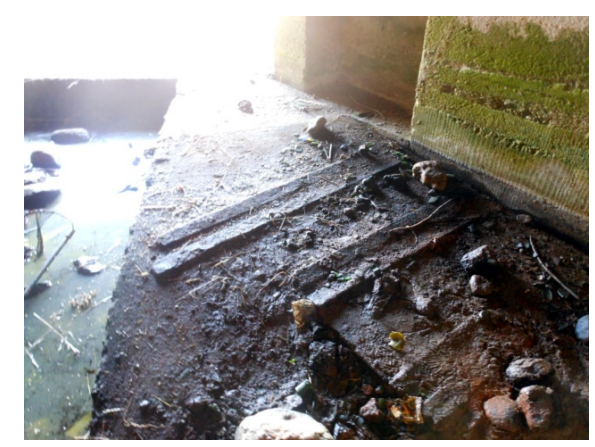

(f)

Figure 18. Pointe de la Roche Pelée St.P.-artillery battery-(a) R677 front fire room aperture, (b) side protective wing, (c) protections of the front side aperture of the fire room, (d) fire room - at the center obstructed rear side aperture, on the left side and on the right sides, entrances of the ammunition rooms, (e) air intakes and conduit of the combat gas extraction system, (f) rests of the rails of the vibration dampening on the floor.

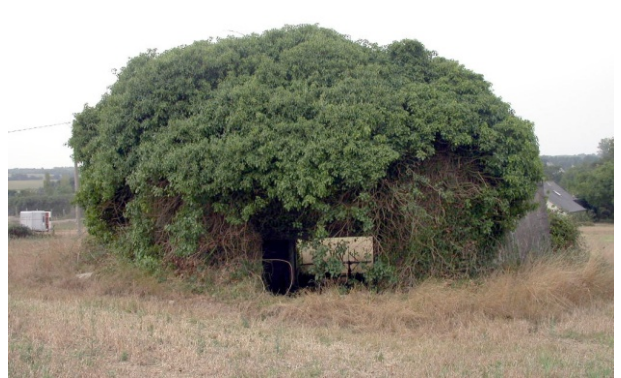

(a)

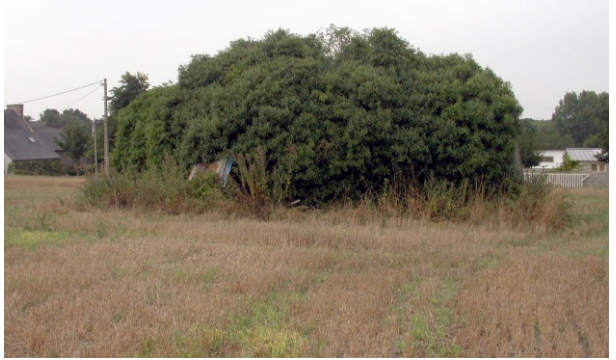

(b) 


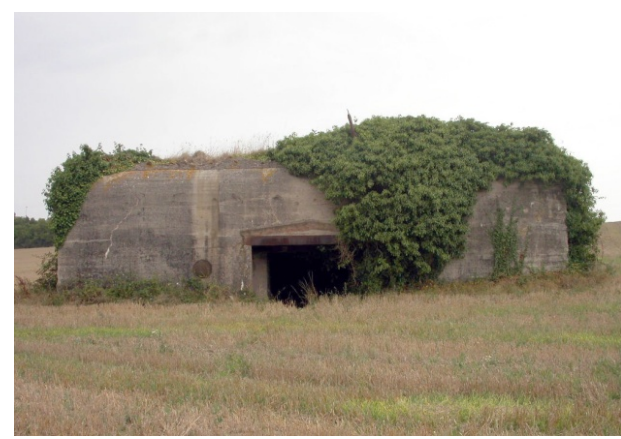

(c)

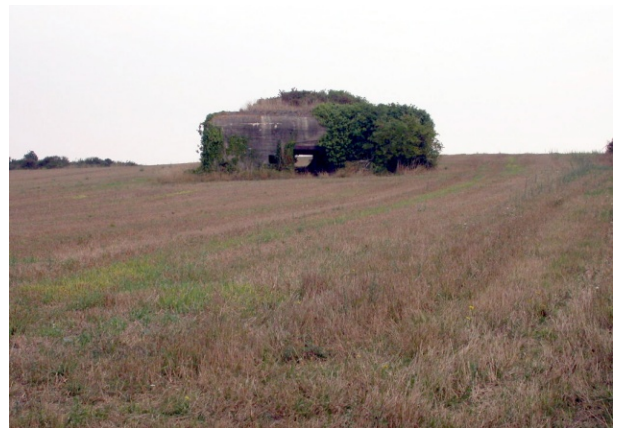

(e)

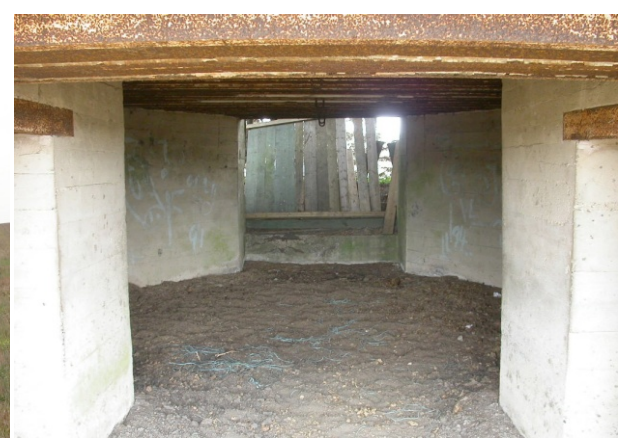

(d)

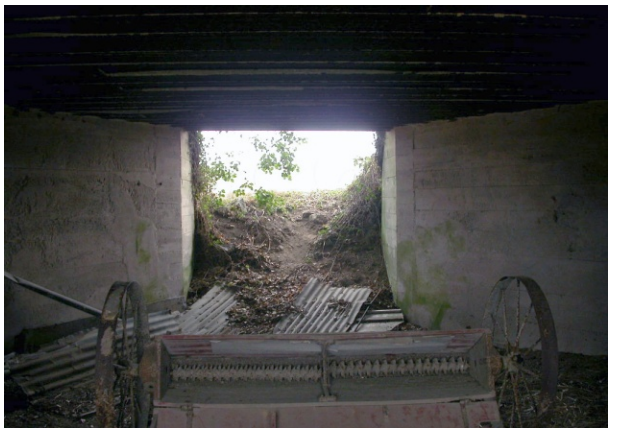

(f)

Figure 19. La Brousette St.P._-artillery battery-(a) first bunker R669, front side covered by the vegetation with front side aperture of the fire room, (b) first bunker R 669, rear side covered by the vegetation, (c) second bunker R669, rear side partially covered by the vegetation, (d) second bunker R 669, interior of the fire room, on the left and on the right sides entrances of the ammunition rooms, in the middle front side aperture of the fire room, (e) third bunker R669, rear side partially covered by the vegetation, (f) third bunker R669, interior of the fire room used as store of agriculture devices, in the middle front side aperture of the fire room.

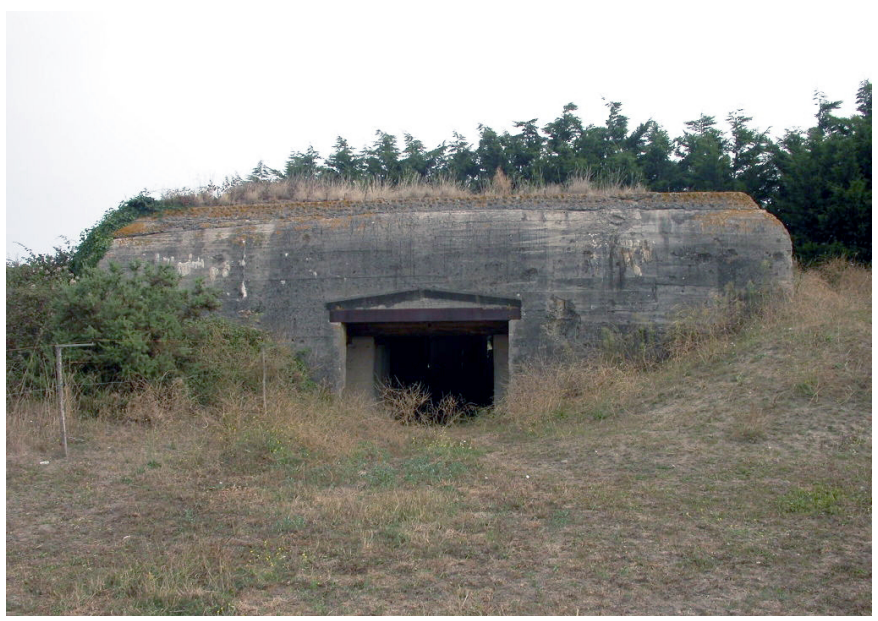

Figure 20. La Brousette St.P.—artillery battery—fourth bunker R669, rear side partially covered by the vegetation and rear side aperture of the fire room.

\section{La Ville es Meniers St.P. 155a-Artillery Battery}

La Ville es Meniers St.P. $155 \mathrm{a}$ artillery battery $\left(48^{\circ} 36^{\prime} 56.41^{\prime \prime N}, 02^{\circ} 3^{\prime} 46.66^{\prime \prime} \mathrm{W}\right)$ was com- 
posed by four bunkers R611 for $150 \mathrm{~mm}$ gun and one bunker R621 shelter for a group (Sakkers, 2001). As shown in an image of 1948 the bunkers R611 were semi-circle disposed with at the center the bunker R621 (Figures 21-23).

The visit of the battery took place on August 2003 and permitted to ascertain that the bunkers were included in the surface of the Dinard Mobil-Homes Store, and that their external sides were occupied by materials of the Store. Their concrete structures were in a good preservation state without damages due to the combats. They were deprived by the original internal furniture and reused as material stores of the Store.

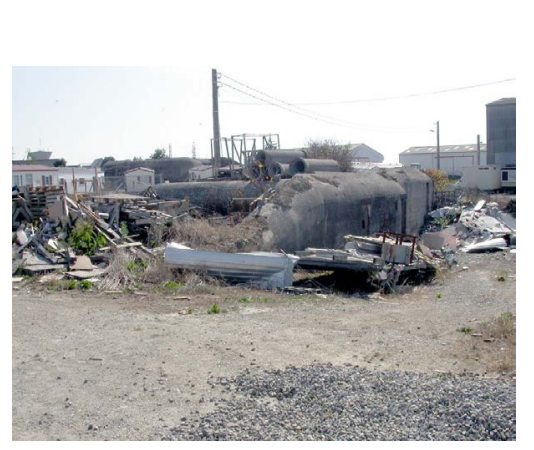

(a)

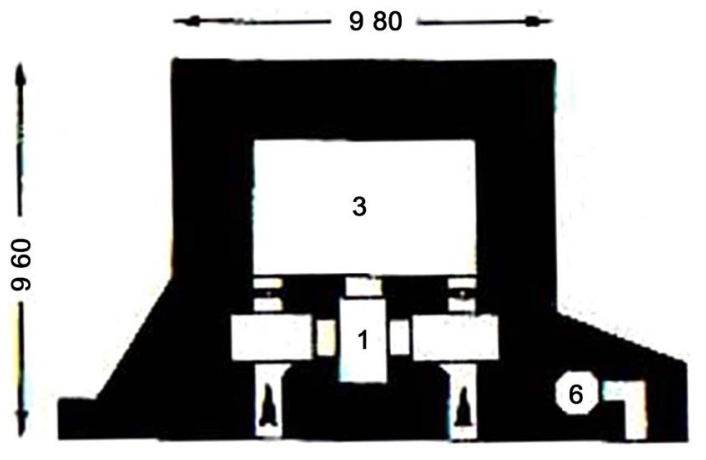

(b)

Figure 21. La Ville es Meniers St.P. 155a-artillery battery-(a) Bunker R621, front side with protective wing, (b) bunker R621 plan: 1. gas lock, 3. group room, 6. uncovered lookout post (Rudi, 1988).

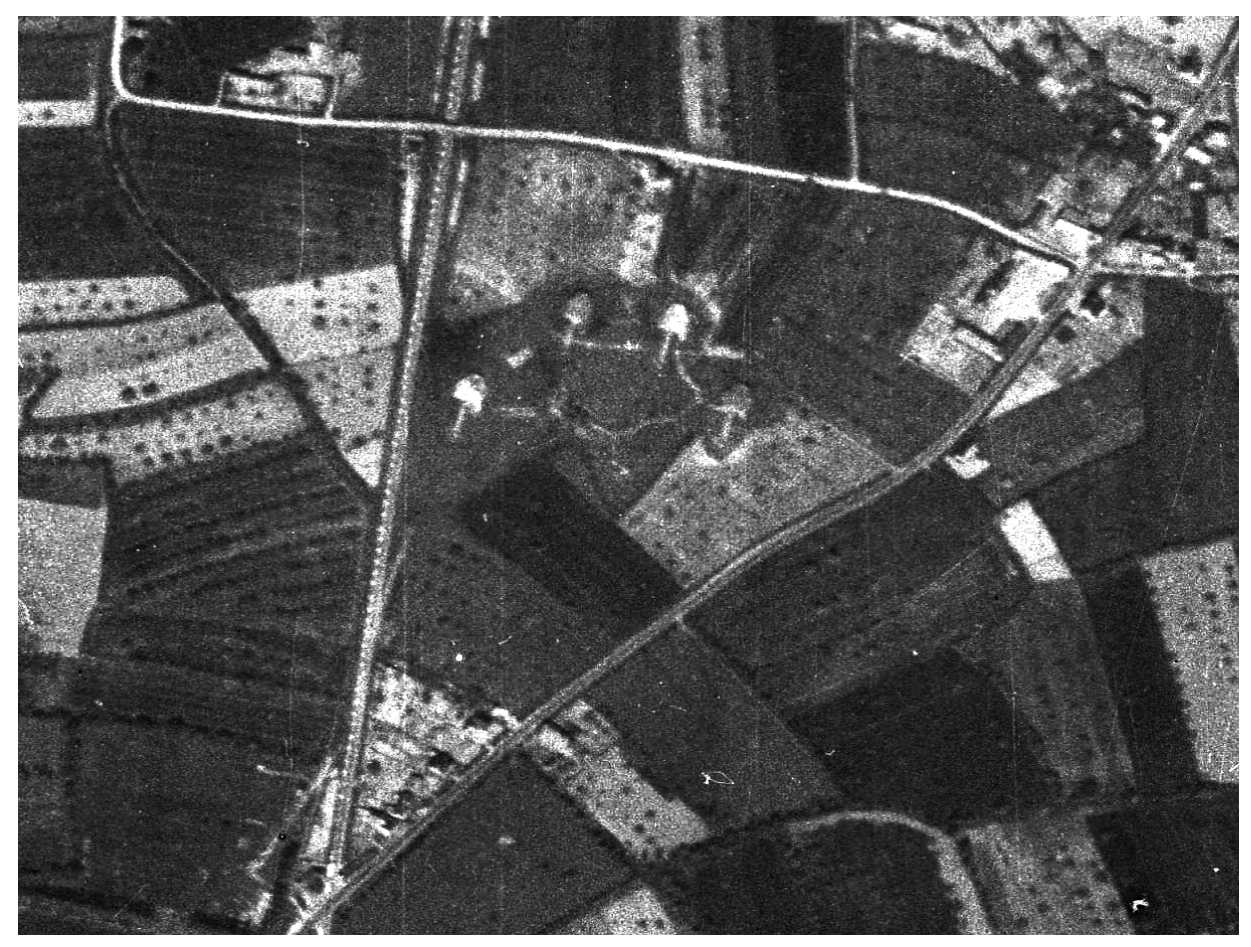

Figure 22. La Ville es Meniers St.P. 155a-artillery battery-semi-circular disposition of the four bunkers R 611 with at the centre, poorly visible, in black, the bunker R621 IGNF_PVA_1-0_1948-04-16_C3639-0511_1948_MISSIONBRETAGNE10_0187. 


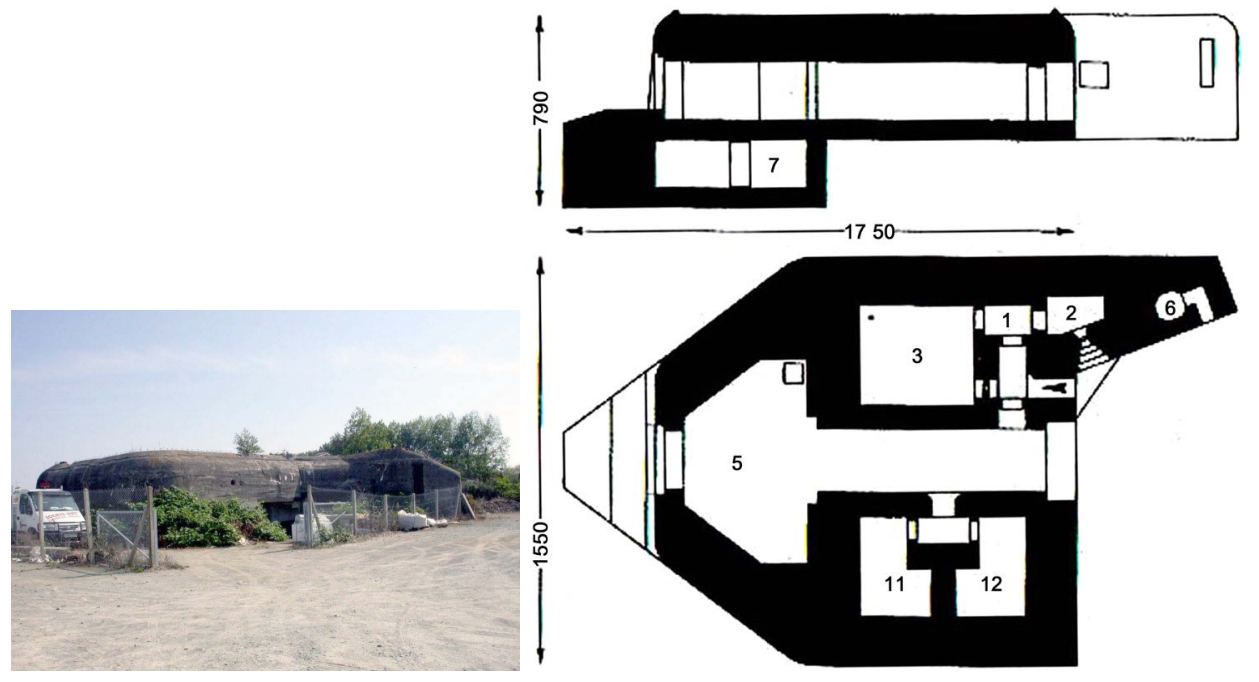

(a)

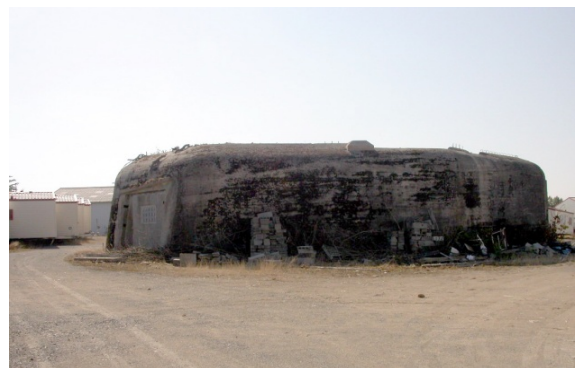

(c)

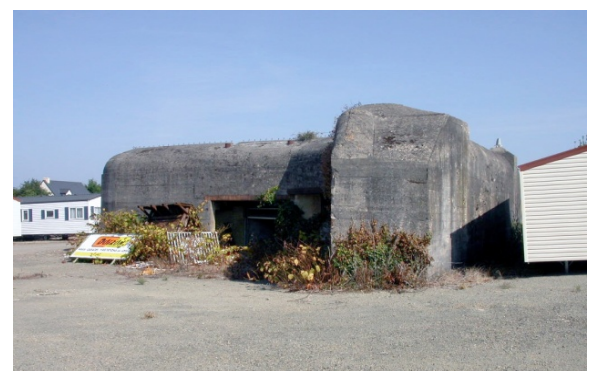

(e)

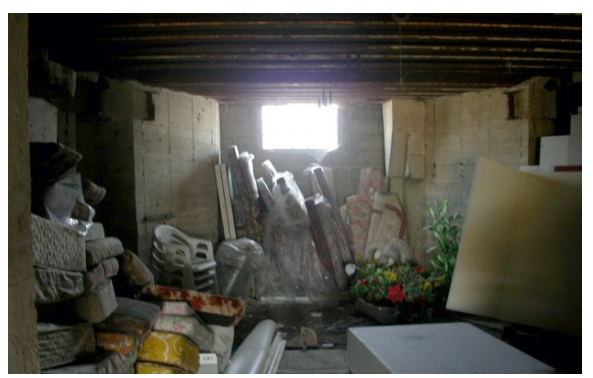

(d)

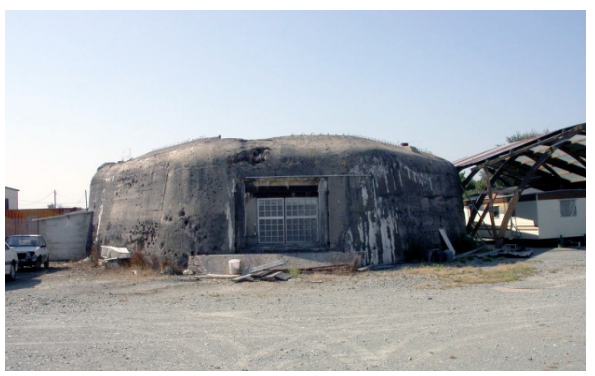

(f)

Figure 23. La Ville es Meniers St.P. 155a-artillery battery-(a) first bunker R611—rear side partially covered by the vegetation, rear side aperture of the fire room and side protective wing with entrance to the uncovered lookout post, (b) R611 bunker plan: 1. gas lock, 2. close combat room, 3. group room, 5. fire room, 6. uncovered lookout post, 7. exhausted shell cases pit, 11. grenades room, 12. cartridge room (Rudi, 1988), (c) second bunker R611, side view, (d) second bunker R611, fire room filled with materials of the Dinard Mobil-Homes Store, on the metal ceiling two joints for the lifting of the gun, (e) third bunker R611 rear side partially covered by the vegetation with rear side aperture of the fire room, (f) fourth bunker R611, front side with front side aperture of the fire room.

\section{Frémur Dam W. 675}

On the board of the river Frémur, for the defence of the South East part of the Festung were positioned the W. 685, W. 682, S. 680, W. 675, S. 236, W. 672, S. 670 (Dupont, 
1994) (Figure 1) (Sakkers, 2001). The Frémur dam W. 675 (Figures 24-39) identified also as AOK 7, KVA A1, KvGr. Rance, KvUGr. Festung St. Malo, Le Pont és Omnés, Ra 675 (Sakkers, 2001), not far from the present airport of Dinard-Pleurtuit (Dahiot, 2009), (Lippmann, 2012), (Tomezzoli, 2014), was composed by the bunkers R621 (Gruppenunterstand-group bunker), R628 (Gruppeunterstand am Vorderhang-group bunker with forward apron), R630 (MG Shartenstand mit Panzerplatte-embrasured MG emplacement with armored plating), R504 (Pak-Unterstellraum mit Gruppe-anti-tank gun bunker with crew quarters).

The visits took place on 19th August 2005 and on 14th August 2009. The dam and the bunkers were easily identified except the bunker R630. The dam of German construction still fulfilled its original duty of creating a barrage on the Frémur. Its concrete structure (Figures 25-27) was in a perfect preservation state, still preserving the sluice regulating mechanism of origin. In case of necessity, it was considered to be destroyed so that the water exiting its basin would have protected the south-east side of the Festung interdicting the allied access.

The sluice still permitted the evacuation of the water in excess in the dam basin as well as the return of the salmons to their native places. On the surface of the dam was well visible, disposed zig-zag, the extremities of rails used as reinforcement.

The bunker R621 (Figures 28-33) had superimposed a garage and the group room

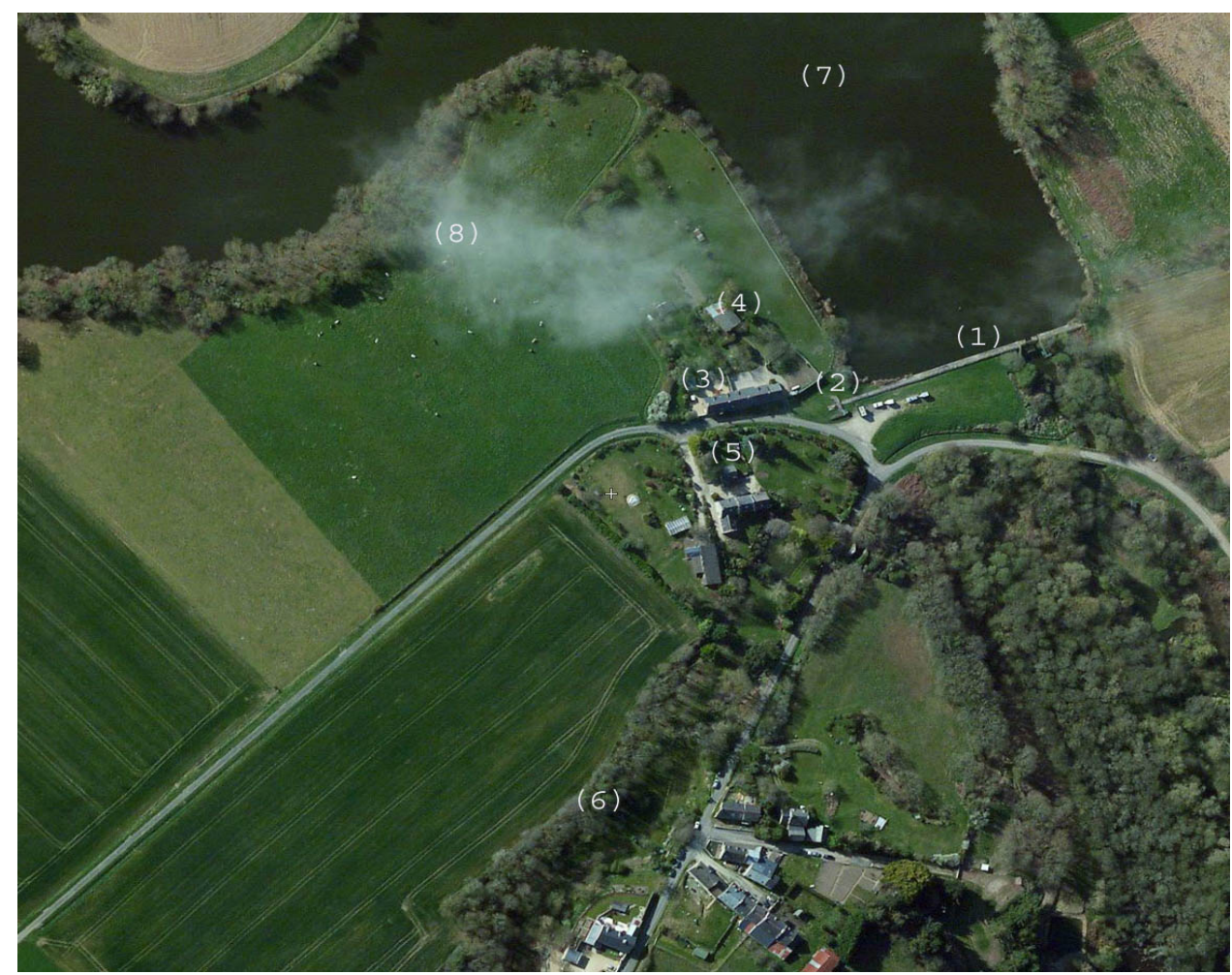

Figure 24. Frémur dam W. 675-(1). dam, (2). dam defence tobruck stand, (3). farm, (4). bunker R621 $\left(48^{\circ} 34^{\prime} 39.3^{\prime \prime} \mathrm{N}, 02^{\circ} 06^{\prime} 6.4^{\prime \prime} \mathrm{W}\right)$ surmounted by a garage, (5). bunker R $504\left(48^{\circ} 34^{\prime} 41.4^{\prime \prime} \mathrm{N}\right.$, $\left.02^{\circ} 06^{\prime} 6.1^{\prime \prime W}\right)$, (6). German railway bridge $\left(48^{\circ} 34^{\prime} 46.5^{\prime \prime} \mathrm{N}, 02^{\circ} 06^{\prime} 3.2^{\prime \prime} \mathrm{W}\right)$, (7). Frémur river, (8) bunker R628 (48 $\left.34^{\prime} 38^{\prime \prime} \mathrm{N}, 2^{\circ} 06^{\prime} 01.0^{\prime \prime} \mathrm{W}\right)$ [Flash Earth]. 


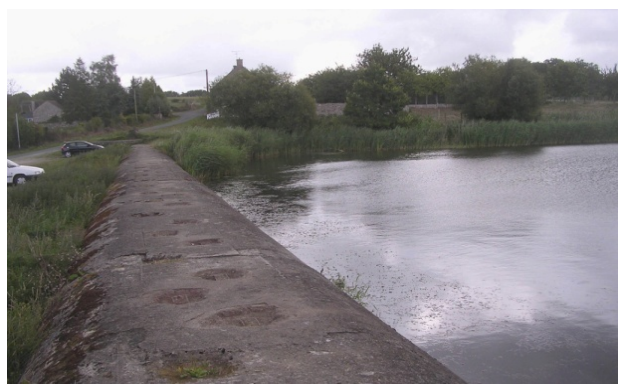

(a)

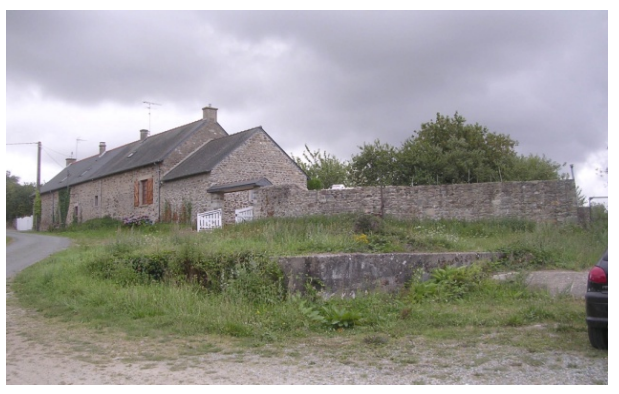

(b)

Figure 25. Frémur dam W. 675-(a) zig-zag extremities of the reinforcement rails, (b) on the upper left the farm possible lodgement of German soldiers, on the lower right the tobruck stand for the close defence of the dam.

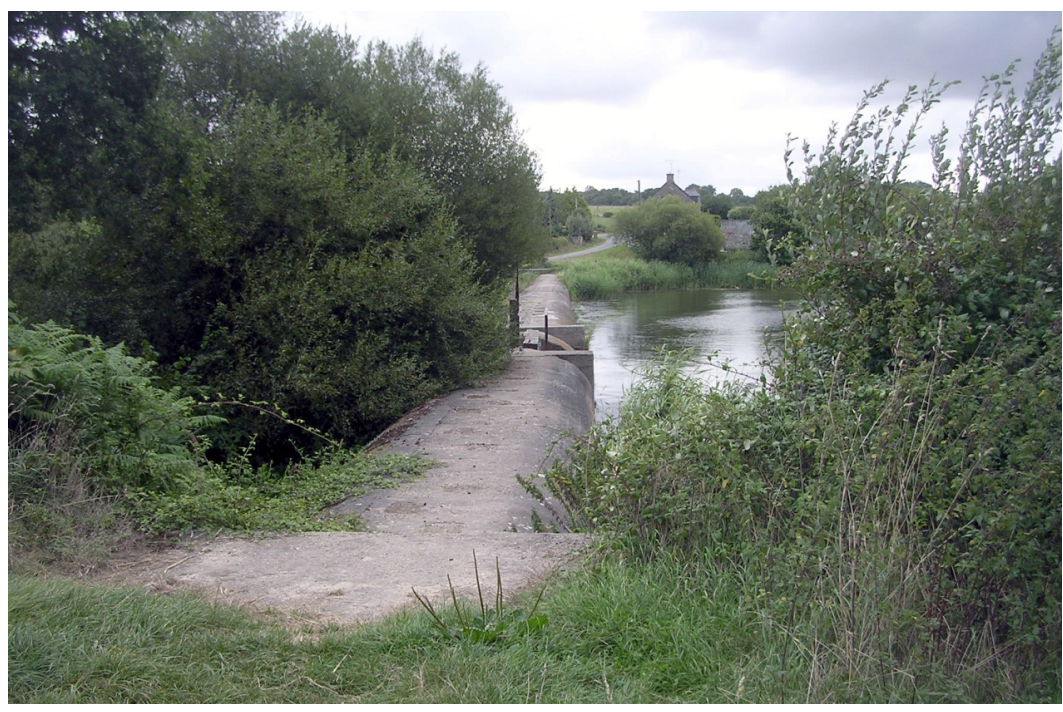

Figure 26. Frémur dam W. 675-dam sluice, in the middle the zig-zag extremities of the reinforcement rails, in the foreground the farm.

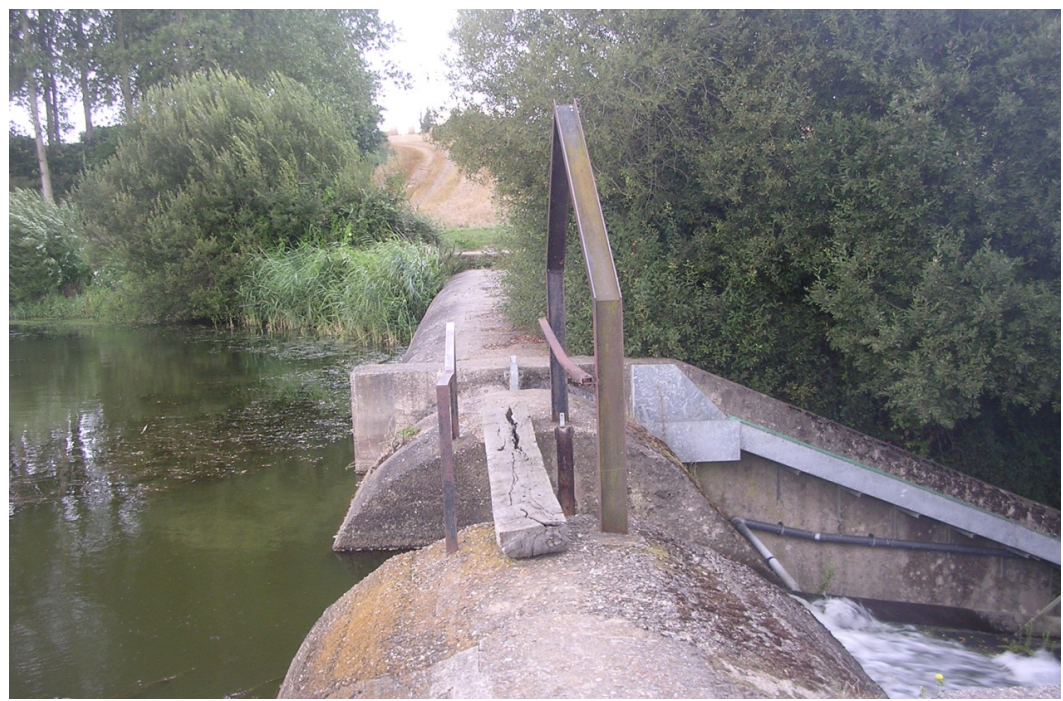

Figure 27. Frémur dam W. 675-dam sluice mechanism. 
for the personnel, used as wine cellar, so that the bunker preservation in the near future is ensured. Only one of the two entrances at the end of a staircase permitted the access to the bunker (Figure 28). The uncovered lookout post, its entrance and the protection wings were covered by the terrain and no longer visible. All the original furniture disappeared with the exception of the 483 P2 armored blades of the close combat rooms and the frames of the internal armored doors. The owner was congratulated for the cleanliness state of the interior of the bunker.

The bunker R504 (Figures 34-37) (Dupont, 2014) presented a well preserved concrete structure. All the original furniture as well as the double door of the gun garage disappeared, but the internal armoured doors were at their places and perfectly rotatable.

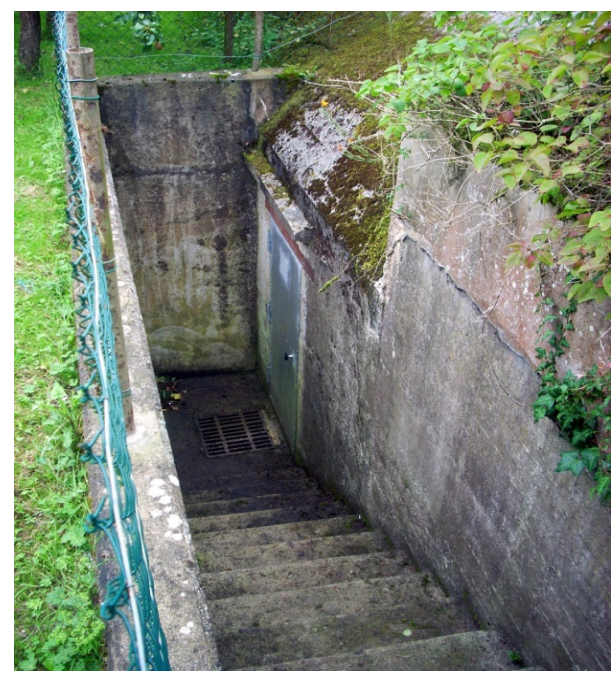

(a)

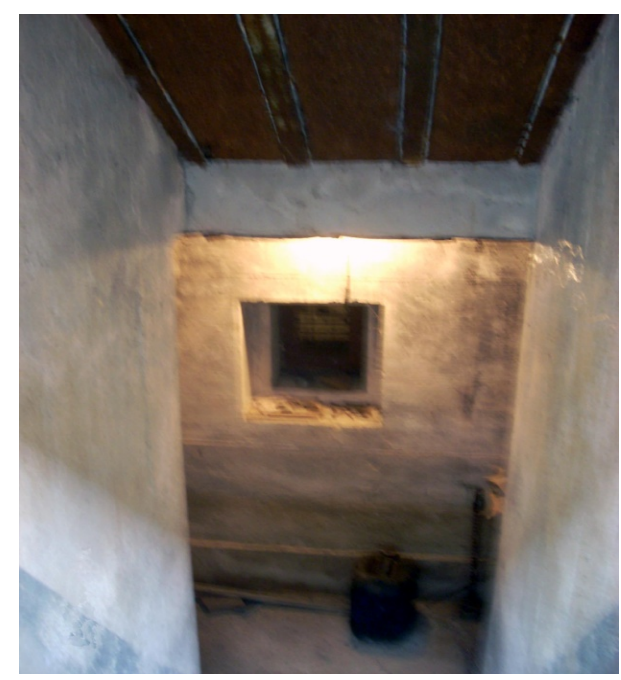

(b)

Figure 28. Frémur dam W. 675-(a) bunker R621, staircase and entrance of the bunker, (b) bunker R621, embrasure of one close combat room.

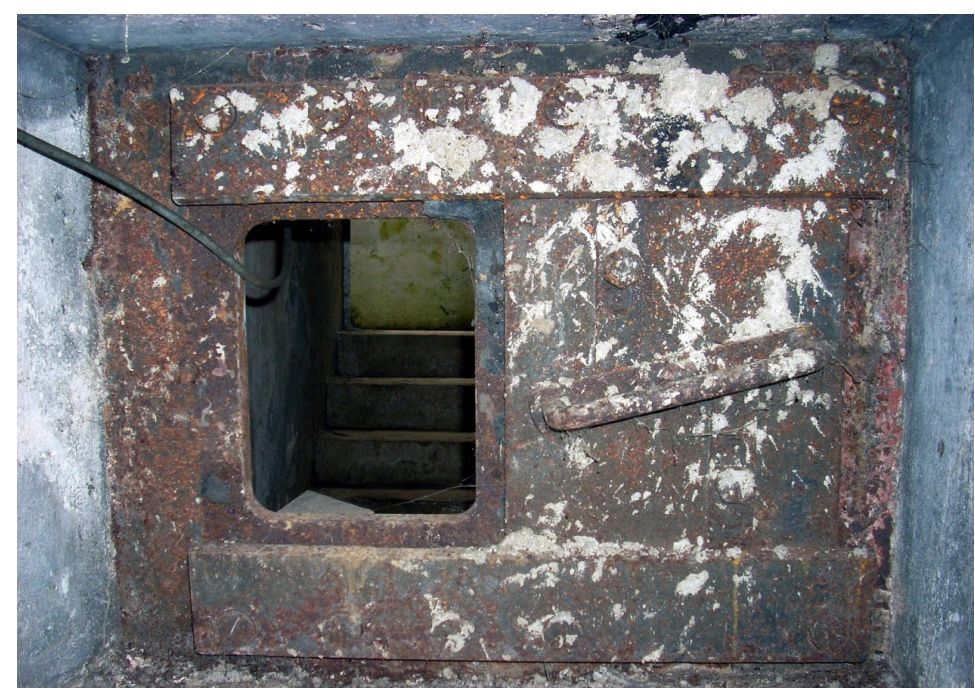

Figure 29. Frémur dam W. 675-bunker R621, 483 P2 armored blade of one close combat room. 


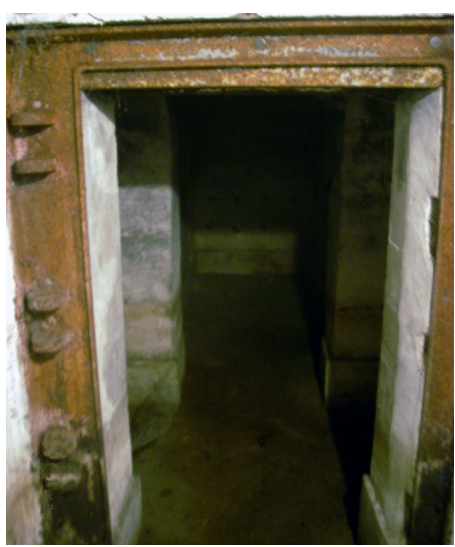

(a)

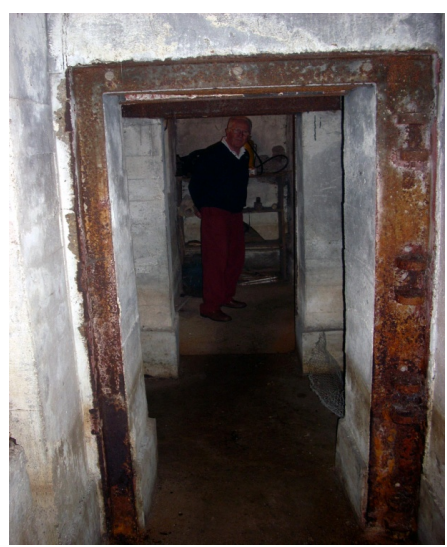

(b)

Figure 30. Frémur dam W. 675-(a) bunker R621, frame of one disappeared armored door and entrance to the group room, (b) bunker R621, frame of the other disappeared armored door and entrance to the group room.

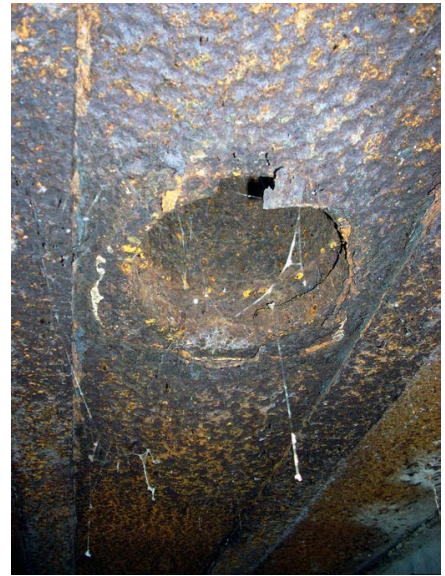

(a)

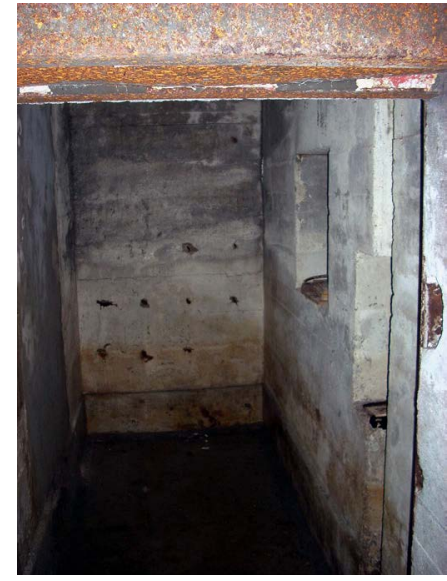

(b)

Figure 31. Frémur dam W. 675-(a) bunker R621, metallic ceiling of the group room, with hole of a chimney, (b) bunker R621, on the right, bunker second entrance with embrasure of one close combat room.

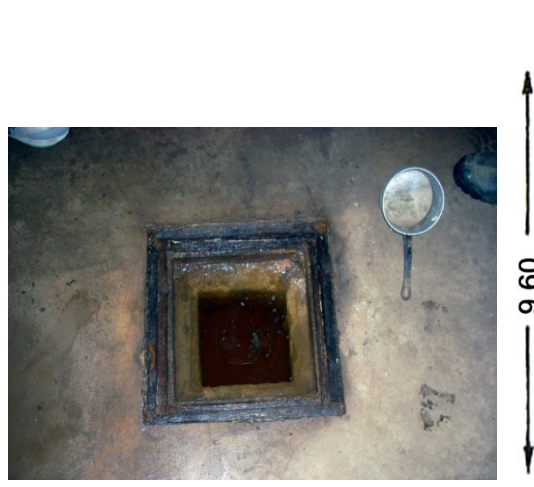

(a)

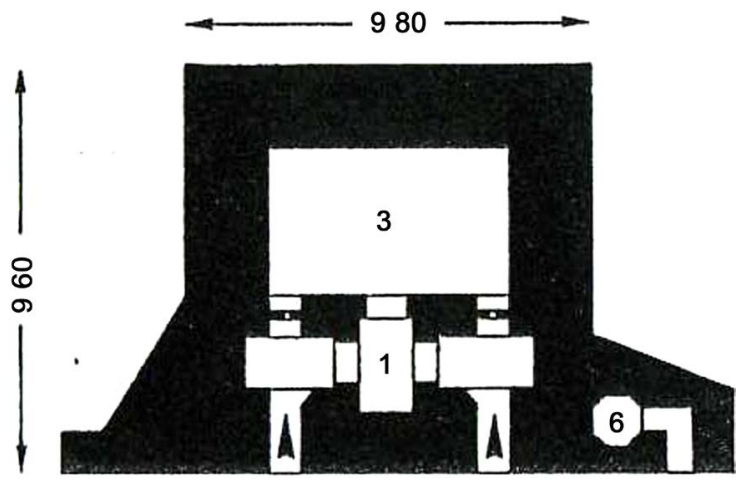

(b)

Figure 32. Frémur dam W. 675-(a) collecting water well on the floor of the group room, (b) bunker R621 plan: 1. gas lock, 3. group room, 6. observation post (Rudi, 1988). 


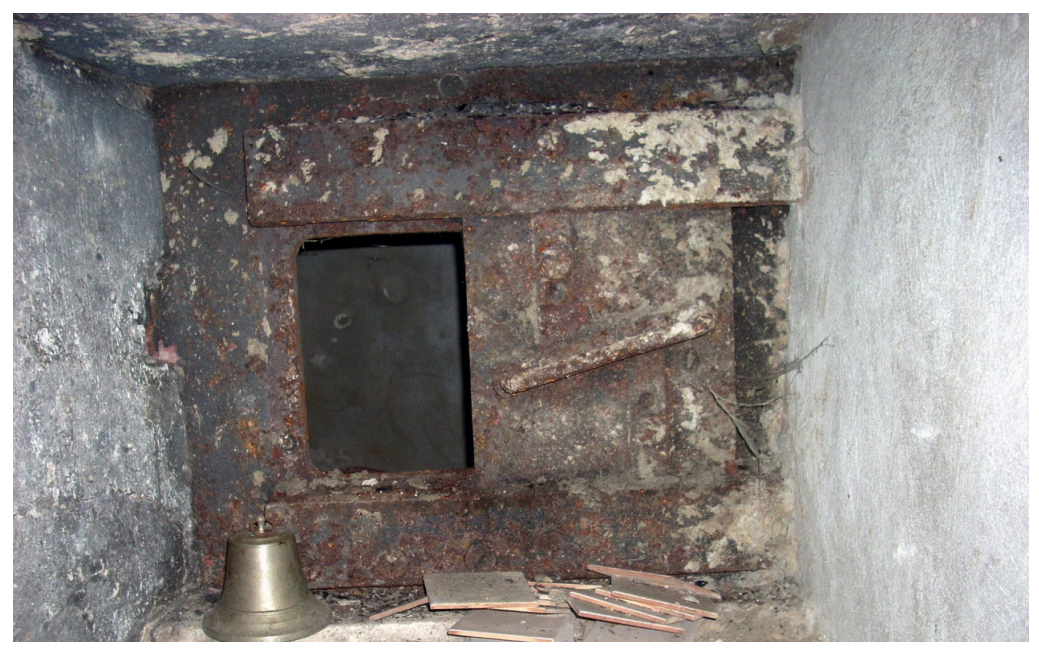

Figure 33. Frémur dam W. 675-bunker R621, 483 P2 armored blade of the other close combat room.

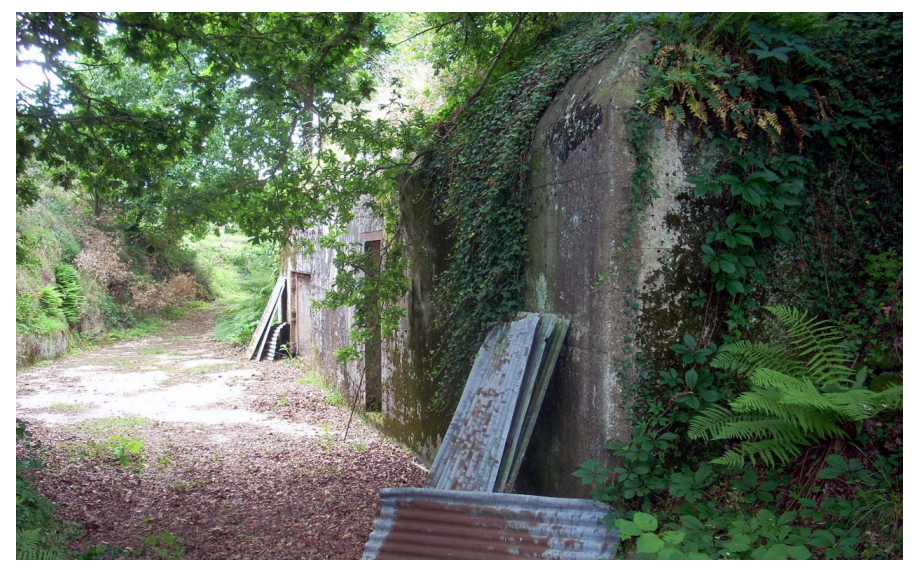

Figure 34. Frémur dam W. 675-bunker R504, on the left aperture of gun garage, in the middle entrance to the bunker.

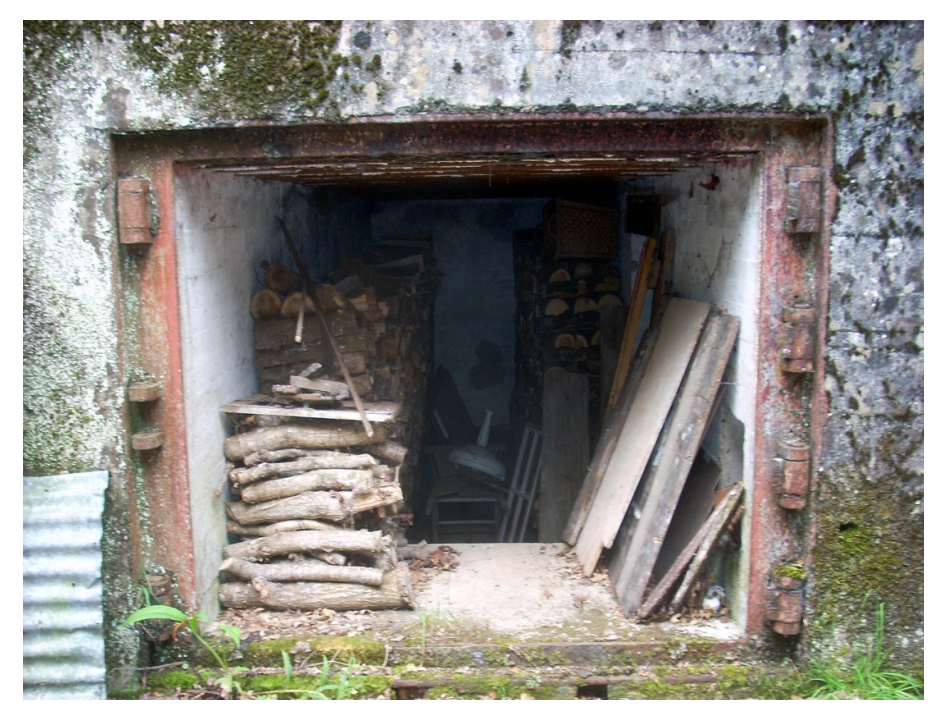

Figure 35. Frémur dam W. 675-bunker R504, frame of the double armored door of the gun garage filled with materials. 


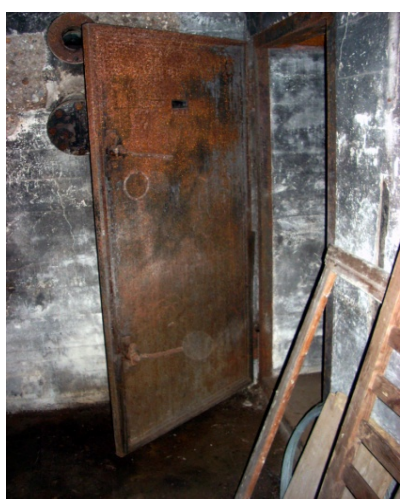

(a)

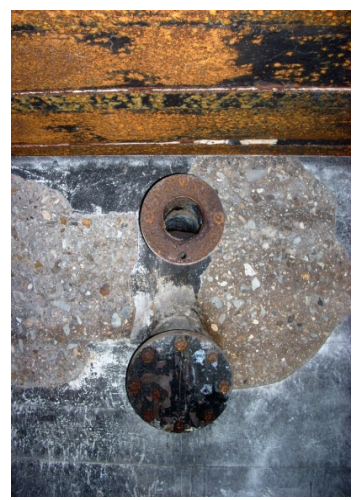

(b)

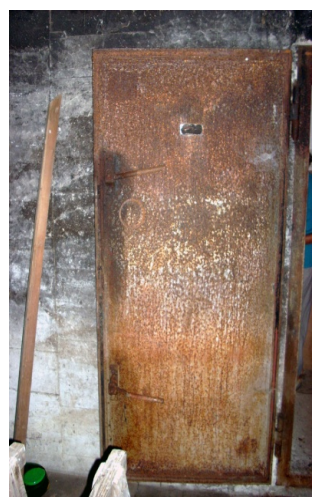

(c)

Figure 36. Frémur dam W. 675-bunker R504: (a) gas protective armored door 19 P7, (b) aeration conduits, (c) gas protective armored door 19 P7.

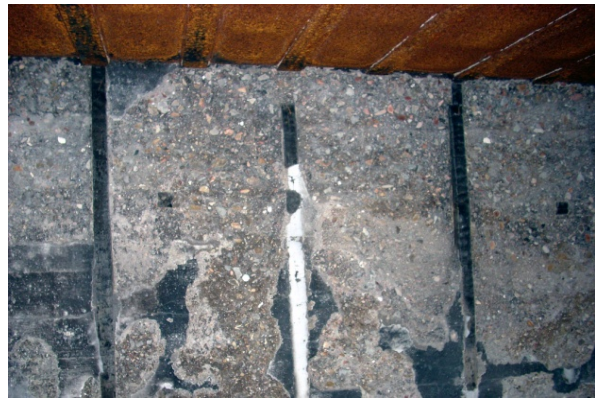

(a)

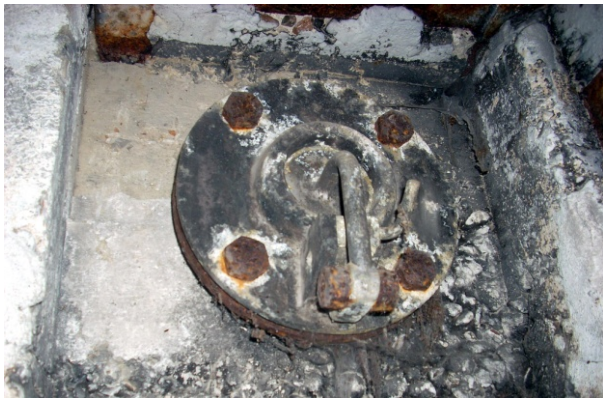

(c)

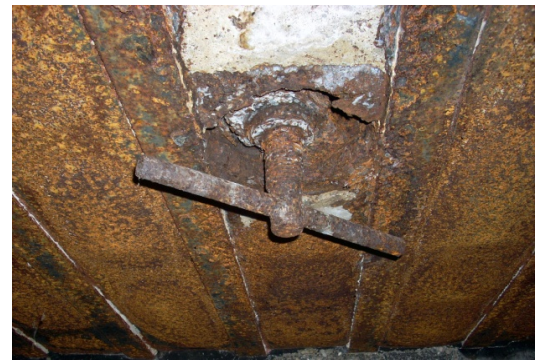

(e)

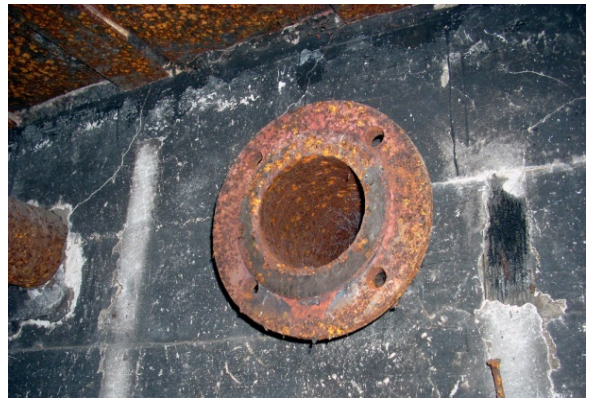

(b)

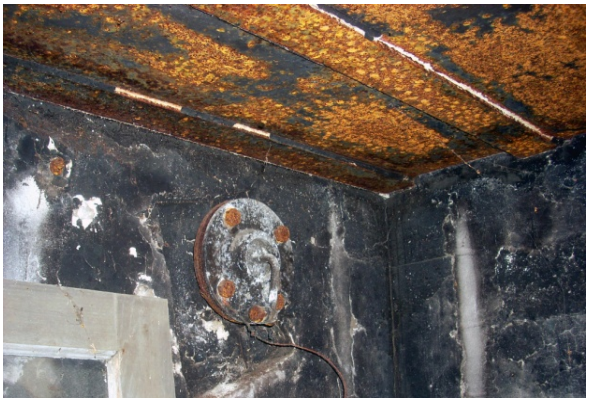

(d)

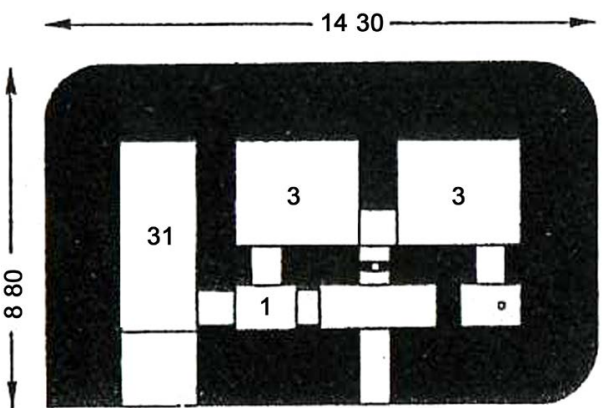

(f)

Figure 37. Frémur dam W. 675-bunker R 504: (a) concrete wall and metal ceiling, (b) aeration conduit, (c) (d) one way conduit, (e) handle of the periscope, (f) bunker R504 plan: 1. gas lock, 3. crew rooms, 31. gun garage (Rudi, 1988). 


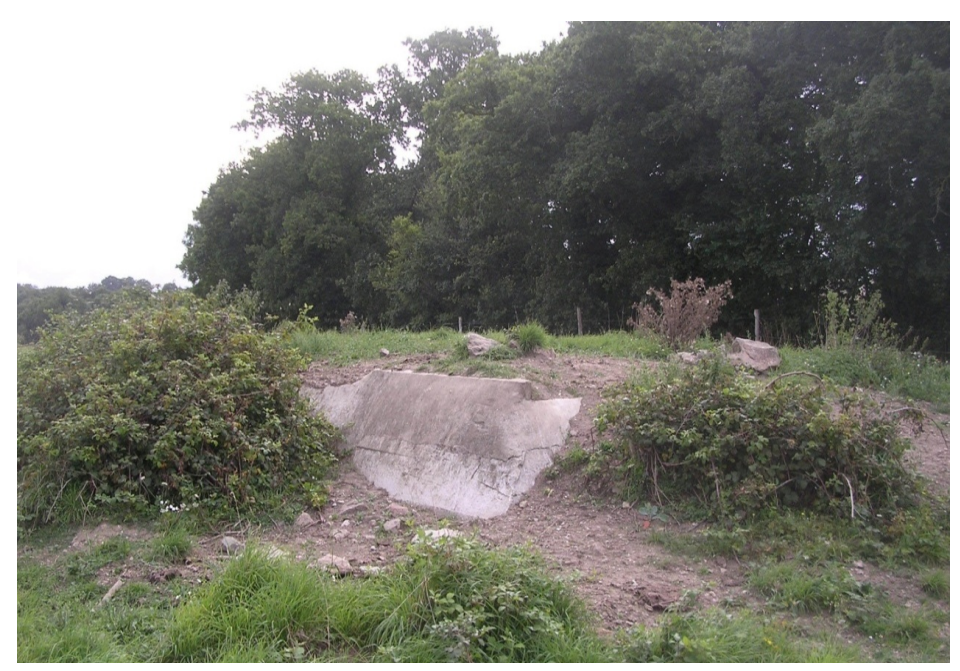

Figure 38. Frémur dam W. 675-bunker R628 covered by the terrain.

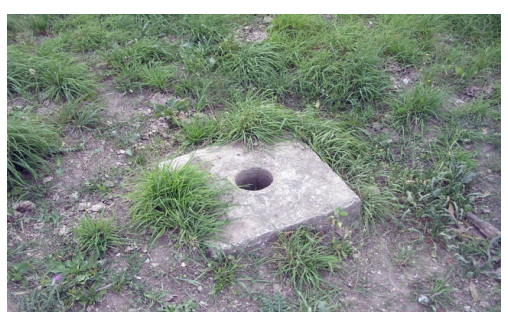

(a)

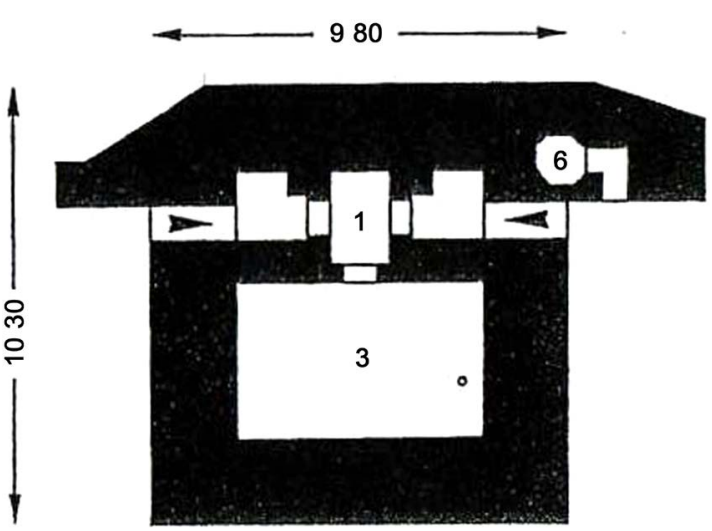

(b)

Figure 39. Frémur dam W. 675-bunker R 628: (a) external base of the periscope (b) R628 bunker plan: 1. gas lock, 3. group room, 6. uncovered lookout post (Rudi, 1988).

\section{Ruins of the German Railway Bridge}

Mr. C. Segalin, inhabitant of Le Verger (Pleurtuit) has indicated the position of a German railway bridge, engulfed by the vegetation, not far from W. 675. The visit took place on 14th August 2009. It was possible to ascertain that, although covered by the vegetation, the concrete structure of the bridge heads and the supports of the railway were well preserved (Figure 40 and Figure 41). The search on the terrain for remains of a railway was unsuccessful. It is therefore possible that the bridge was part of an advancing project of providing railway line for the supplying in materials and ammunitions the W.s and S.s along the Frémur, interrupted by the Normandy landing and the battle of Saint-Malo.

\section{Conclusion}

Unfortunately many of the above German military structures did not survive the reconstruction of Saint-Malo. The French military authorities did not provide a conser- 


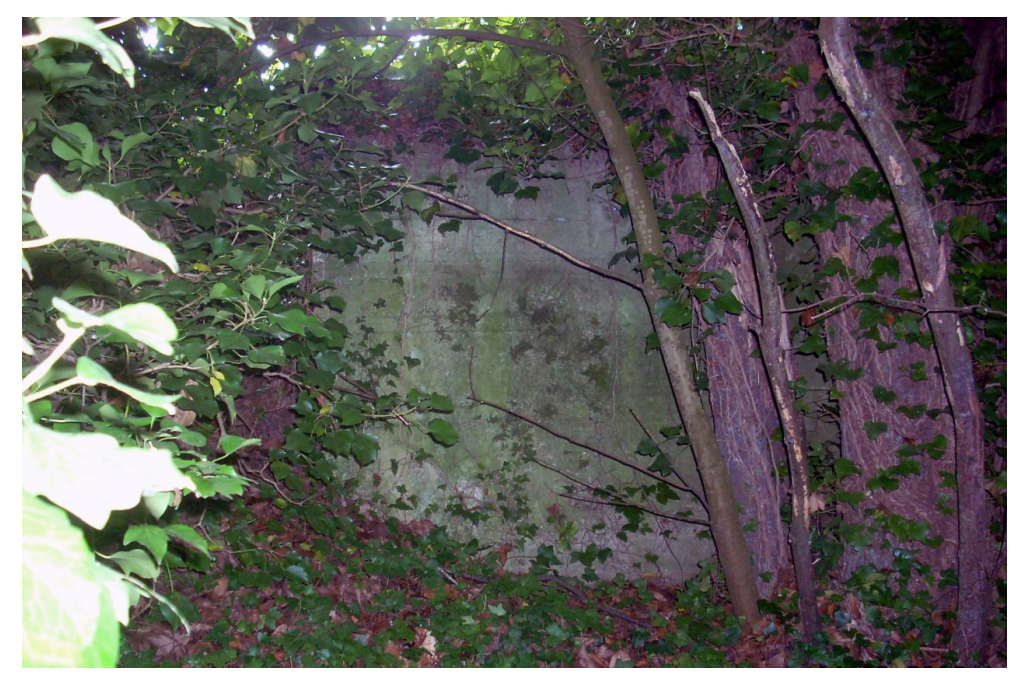

Figure 40. German Railway Bridge-one of the bridge heads.

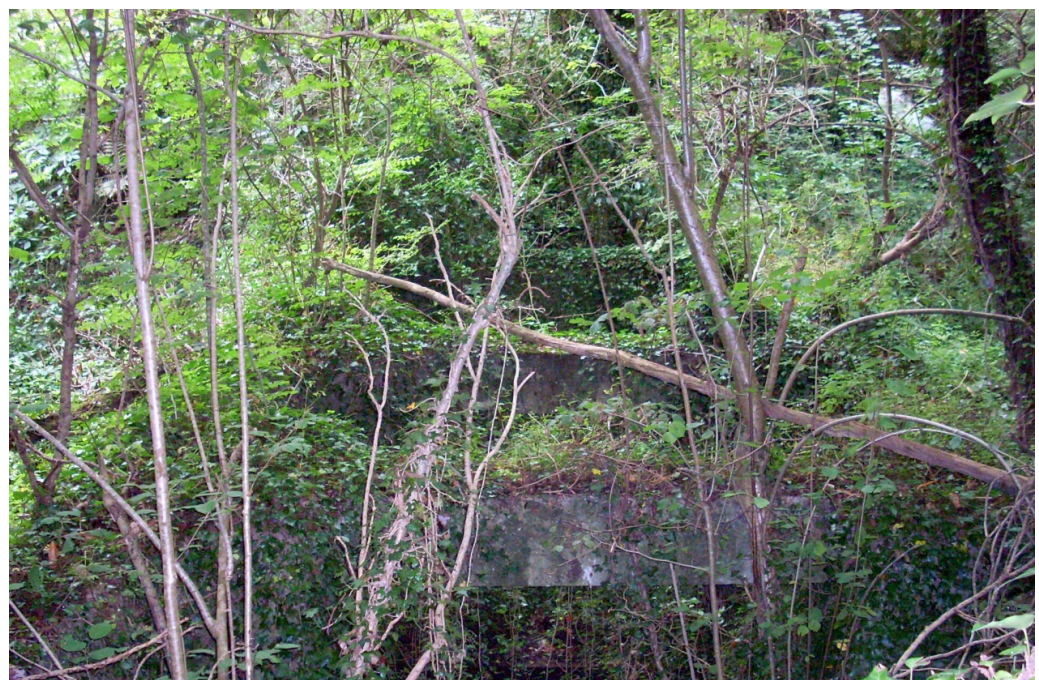

Figure 41. German Railway Bridge-railway supports covered by the vegetation.

vation plan for them and the administrative authorities did not integrate them in the city economy probably for ameliorating the accessibility to the port and probably because of the deliberate decision of deleting memories of a sad period. Outside the city, many of them are visible, accessible and sometime integrated for satisfying agricultural and storage exigencies. They testify the confidence of the Germans in military static offensive and defensive structures. Evidently, the geo-political situation is now evolved as well as the modern military doctrines based on rapid first strike and precision bombing, therefore, they will never recover a military importance. Therefore, we can look to them neutrally, as a contemporary archaeology subject, although they witness of a recent tragic period in the life of Saint-Malo.

\section{Acknowledgements}

We are grateful to Mr. Dupont P. inhabitant of Dinard and to Mr. Segalin C. inhabitant 
of Pleurtuit for having guided us during the visits of W. 675 and the site of the German railway bridge.

\section{References}

Beroul, P. (1982). Saint-Malo sous l'Occupation (p. 108). Ouest France.

Brichet, O., \& Peyle, E. (2005). La Marine Allemande à Saint-Malo, 1940-1944 (p. 71, 115). Cancale: Editions du Phare.

Brouard, J.-I., Mercier, G., \& Saibène, M. (2009). La marine marchande française 1939-1945 (p. 121). Paris: JYB-Aventures.

Dahiot, D., Dupont, P., Pottier, L., \& Tomezzoli, G. (2009). Die Infrastruktur des Fliegerhorstes Dinard-Pleurtuit im II. Weltkrieg (p. 53, 42-61). Ausgabe: DAWA Nachrichten.

Dupont, A., \& Peyle, E. (1994). Le Mur de I'Atlantique sur la Côte d'Émeraude (p. 55). Ed. Saint-Malo: Danclau.

Feige, E. (2011). Epaves Malouines. Editions Cristel (p. 158).

Lippmann, H. (2012). Die Flugabwehrsicherung des Fliegerhorstes Dinard-Pleurtuit (p. 60, 4-13). Ausgabe: DAWA Nachrichten.

Pottier, L. (2014a). Private Archive, German General Headquarter Map of the Defenses of the Port of Saint-Malo.

Pottier, L. (2014b). Private Archive, Note No. 144, Secret, 15 Mai 1945, par le Capt. de Corvette De La Bretesche pour le Ministre de la Marine, Référ Note 3344 CAN/T du 23 Avril 1945.

Pottier, L. (2014c). Private Archive, Lettre par Mer Marcel Halna à Mer Louis Pottier, avec croquis de la station allemande de démagnétisation.

Rudi, R. (1988). Typologie du Mur de l'Atlantique (p. 923). Beetsterzwaag: NUGI.

Sakkers, H. (2001). Festung St.-Malo. Een eindstrijd tot het uiterste 5 aug.-2 sept. 1944 (pp. 131A -133A). Saint-Malo: Koudekerke.

Tomezzoli, G. (2014). Der Gefechtsstand der Flak Abteilung 912 auf dem Gelände des Fliegerhorstes Dinard-Pleurtuit (pp. 20-27, 63). Ausgabe: DAWA Nachrichten.

Tomezzoli, G., \& Pottier, L. (2016). Journey through the Defenses of the Festung Saint-Malo (FR)-1. Social Sciences \& Humanities, 4, 125-142.

Tomezzoli, G., Pottier, L., \& Dahiot, D. (2013). La logistique et les défenses de l'aérodrome de Pleurtuit (Bretagne-FR) pendant la guerre. L'écho de la Cohue No. 14, Patrimoine du Pays de Pleurtuit en Poudouvre.

Wikipedia (2015). https://fr.wikipedia.org/wiki/262_BD_1 
Submit or recommend next manuscript to SCIRP and we will provide best service for you:

Accepting pre-submission inquiries through Email, Facebook, LinkedIn, Twitter, etc. A wide selection of journals (inclusive of 9 subjects, more than 200 journals)

Providing 24-hour high-quality service

User-friendly online submission system

Fair and swift peer-review system

Efficient typesetting and proofreading procedure

Display of the result of downloads and visits, as well as the number of cited articles

Maximum dissemination of your research work

Submit your manuscript at: http://papersubmission.scirp.org/

Or contact ad@scirp.org 